Research Article

\title{
Woody Species Composition, Vegetation Structure, and Regeneration Status of Majang Forest Biosphere Reserves in Southwestern Ethiopia
}

\author{
Semegnew Tadese $\mathbb{D}^{\mathrm{D}},{ }^{1}$ Teshome Soromessa, ${ }^{1}$ Tesefaye Bekele, $^{2}$ and Getaneh Gebeyehu ${ }^{3}$ \\ ${ }^{1}$ Addis Ababa University, Center of Environmental Sciences, Addis Ababa, Ethiopia \\ ${ }^{2}$ Ethiopian Environments and Forestry Research Institute, Addis Ababa, Ethiopia \\ ${ }^{3}$ Assosa University, Department of Biology, Assosa, Ethiopia
}

Correspondence should be addressed to Semegnew Tadese; semetade@gmail.com

Received 20 February 2021; Accepted 19 May 2021; Published 7 June 2021

Academic Editor: Ahmad A. Omar

Copyright (c) 2021 Semegnew Tadese et al. This is an open access article distributed under the Creative Commons Attribution License, which permits unrestricted use, distribution, and reproduction in any medium, provided the original work is properly cited.

\begin{abstract}
The aim of this study was to analyse the species composition, structures, and regeneration of woody plant species and the impacts of site factors on the natural regeneration of tree species in four study sites of MFBR. The vegetation data were collected systematically in 140 plots with the size of $400 \mathrm{~m}^{2}$ for trees; $25 \mathrm{~m}^{2}$ for seedlings, saplings, shrubs, and lianas; and $1 \mathrm{~m}^{2}$ for herbs. Individual tree and shrub $\mathrm{DBH} \geq 5 \mathrm{~cm}$ were measured and counted. The diameter at breast height (DBH), frequency, basal area, importance value index (IVI), and density were used for vegetation structure description and regeneration. A total of 158 plant species belonging to 115 genera, 56 families, and 80 species (51\%) trees, 26 (16\%) shrubs, 19 (12\%) herbs, and 33 (21\%) lianas were identified and recorded. The most dominant families were Euphorbiaceae, Rubiaceae, and Moraceae, each represented by 13 species (7.4\%), 12 species (6.8\%), and 10 species (5.7\%), respectively. The tree densities varied from 1232 to $1478 \mathrm{stem} \mathrm{ha}^{-1}$, sapling density 176.8 to $708.7 \mathrm{stem} \mathrm{ha}^{-1}$, and seedling density 534.7 to $1657.5 \mathrm{stem} \mathrm{ha}{ }^{-1}$, with an average basal area of $63.6 \mathrm{~m}^{2}$ in the study sites. Dracaena afromontana was the most frequent woody species in the MFBR occurring in $90 \%$ followed by Celtis zenkeri (65\%) and Pouteria altissima (62.5\%). The regeneration status of all the woody plant species was categorised as "not regenerate" (9.6\%), "poor" (30.7\%), "fair" (59.5\%), and "good" (10.8\%) in all sites. The correlation result between natural regeneration and site factors revealed both positive and negative relationships. However, the main threat to the biosphere reserve is illegal logging for different purposes. Therefore, awareness creation on sustainable forest management, utilisation, conservation of priority species, and livelihood diversification to the local community and encouraging community and private woodlot plantation in the transitional zone of biosphere reserves are recommended.
\end{abstract}

\section{Introduction}

Ethiopia is the centre of biological diversity because of its wide range of geographical scale $[1,2]$. The various topographic factors with diverse climatic factors have created diversified vegetation types in the country. These make Ethiopia have above 6000 higher plant species, of which about $10 \%$ are endemic [3]. The vegetation type at Majang forest biosphere reserves is part of the moist evergreen Afromontane forest and is found in the southwestern parts of Ethiopia. Most of these moist evergreen Afromontane forests are very crucial for the conservation of fauna and flora as well as water sources for the low land area $[4,5]$. However, moist evergreen Afromontane forest resources are being dwindled at an alarming rate because of anthropogenic disturbance $[6,7]$.

Hence, studying plant population structure and regeneration status is significant to understanding the dynamics of vegetation and their disturbance factors [8]. Stand structure is displaying the distribution of an individual in each species and provides the general regeneration profile of the forest $[9,10]$. Population structure can show whether or not a continuous regeneration and stable population take place. Inspection of species population structure patterns could 
provide vital information about the recruitment status and the sustainability of population management. It is evidence for further planning and conservation strategies and helps recognise forest ecosystems and biodiversity [11].

Regeneration is a vital part of any forest ecosystem dynamics, as well as it regulates the existence of species and restoration of forest land degradation [12], and it could be playing a great role in planning, forest conservation, and sustainable management [13]. Sustainable forest management and utilisation could be possible if there is sufficient evidence available on the regeneration dynamics and factors influencing important canopy tree species [8]. The regeneration status of sample species can be accessed based on total seedling and sapling density dynamics in a given plant community $[9,14]$. As a result, the assessment of population structure and regeneration status is necessary to establish the effective conservation and management of forest resources base [15].

Population dynamics of seedlings, saplings, and tree plant species can demonstrate the regeneration profile of a given species. A population with a sufficient number of seedlings and saplings depicts satisfactory regeneration [16], but a scarce number of seedlings and saplings of the species show a poor regeneration state [17]. Furthermore, the regeneration status of a species is poor if the number of seedlings and saplings is much less than mature individuals [18]. The major causes for the destruction of natural forests are agricultural expansion and overexploitation for various purposes such as fuel wood, charcoal, construction material, and timber [19], which are responsible for the high degradation of regeneration status and population structure of the species in Majang forest biosphere reserves [20].

A biosphere reserve is an area established to conserve the biological and cultural diversity of a region while promoting sustainable economic and social development [21]. The requirements of biosphere reserves should, explicitly, fulfil three basic functions: conservation function, development function, and logistics function [22]. Nowadays, there are 699 biosphere reserves in 120 countries of the world. Out of the total biosphere reserves, 79 are found in 29 African countries, of which Ethiopia has five biosphere reserves such as Kafa besides Yayo, Sheka, Lake Tana, and Majang nominated in 2010, 2012, 2015, and 2017, respectively [23].

The Majang biosphere reserve is located in the Majang zone of the Gambella Peoples National Regional State. The Majang biosphere reserve is a newly established forest biosphere reserve; however, there is no first-hand information on vegetation ecology. For effective management and conservation of the biosphere reserves, detailed baseline information on species composition, population structure, and regeneration status is needed, which are crucial for the conservation and sustainable management of biosphere reserve tree species. The population structure of a tree species is indicative of its past distraction and environment. Moreover, it can be used to forecast its future status of Majang forest biosphere reserves [24]. Therefore, the objectives of this study are (1) to assess species composition, structures, and regeneration of woody plant species and (2) to analyse the impacts of site factors on the natural regeneration of tree species of Majang forest biosphere reserves.

\section{Materials and Methods}

2.1. Description of Study Area. This study was conducted in the Majang Forest Biosphere Reserve (MFBR), which is found in the Majang Zone, Gambella Peoples National Regional State of Ethiopia. It has unique biogeography and shares a border with the Illubabor zone of the Oromia regional state and Sheka and Bench-Maji zones of the Southern Nations, Nationalities, and Peoples (SNNP). It covers a total area of 233,254 ha of forest, woodland, agricultural and rural settlement, and towns (Figure 1). The MFBR is located between $07^{\circ} 08^{\prime} 00^{\prime \prime}-07^{\circ} 50^{\prime} 00^{\prime \prime}$ latitude and $34^{\circ} 50^{\prime} 00^{\prime \prime}-35^{\circ} 25^{\prime} 00^{\prime \prime}$ longitude, and the area has an altitude of $562 \mathrm{~m}$ to $2444 \mathrm{~m}$ [1].

The climate of the zone is generally characterised by a hot and humid type, which is marked on most rainfall maps of Ethiopia as being the wettest part of the country. The annual average rainfall is $1774 \mathrm{~mm}$, and means annual minimum and maximum monthly temperature ranges between 13.9 and $31.8^{\circ} \mathrm{C}$ in the Tinishu Meti metrological station. The annual average rainfall is $2053 \mathrm{~mm}$, and means annual minimum and maximum monthly temperature ranges between 11.8 and $29.7^{\circ} \mathrm{C}$ in the Ermichi metrological station. The maximum average monthly temperature is in February $\left(29.8^{\circ} \mathrm{C}\right.$ and $\left.31.8^{\circ} \mathrm{C}\right)$, while the minimum is in January $\left(11.9^{\circ} \mathrm{C}\right.$ and $\left.13.9^{\circ} \mathrm{C}\right)$ in Ermichi and Tinishu Meti, respectively. The maximum rainfall is between April and October and low rainfall from November to March (NMSA, 2019) (Figure 2).

The pattern of land use is changing from time to time depending on cultural background and socioeconomic change. There is a changing trend in the major land use/land cover types in Majang forest biosphere reserves [19] (Table 1).

According to the vegetation classification of Ethiopia [25], the major vegetation types of the Majang biosphere are Montana evergreen forest, low-land semievergreen forest, and riparian vegetations [26]. Besides, the vegetation of this area has different categories in terms of life forms such as high natural forest, woodlands, bushlands, and grasslands. The dominant families were Euphorbiaceae, Asteraceae, Moraceae, Fabaceae, Poaceae, Solanaceae, Rubiaceae, and Sapotaceae.

2.2. Sampling Design. A reconnaissance survey was conducted from 15 February up to 10 May 2020 in Majang biosphere reserves to inspect a local area. The forest cover and vegetation pattern related to topography and other apparent environmental conditions were recognised. Local variation of forest cover and management measures was assessed. Some geographical location of each forest was recorded to delineate the area. Then, the measurement of forest cover (ha) was determined using Google Earth map and ground survey GPS coordinates (Figure 1). 


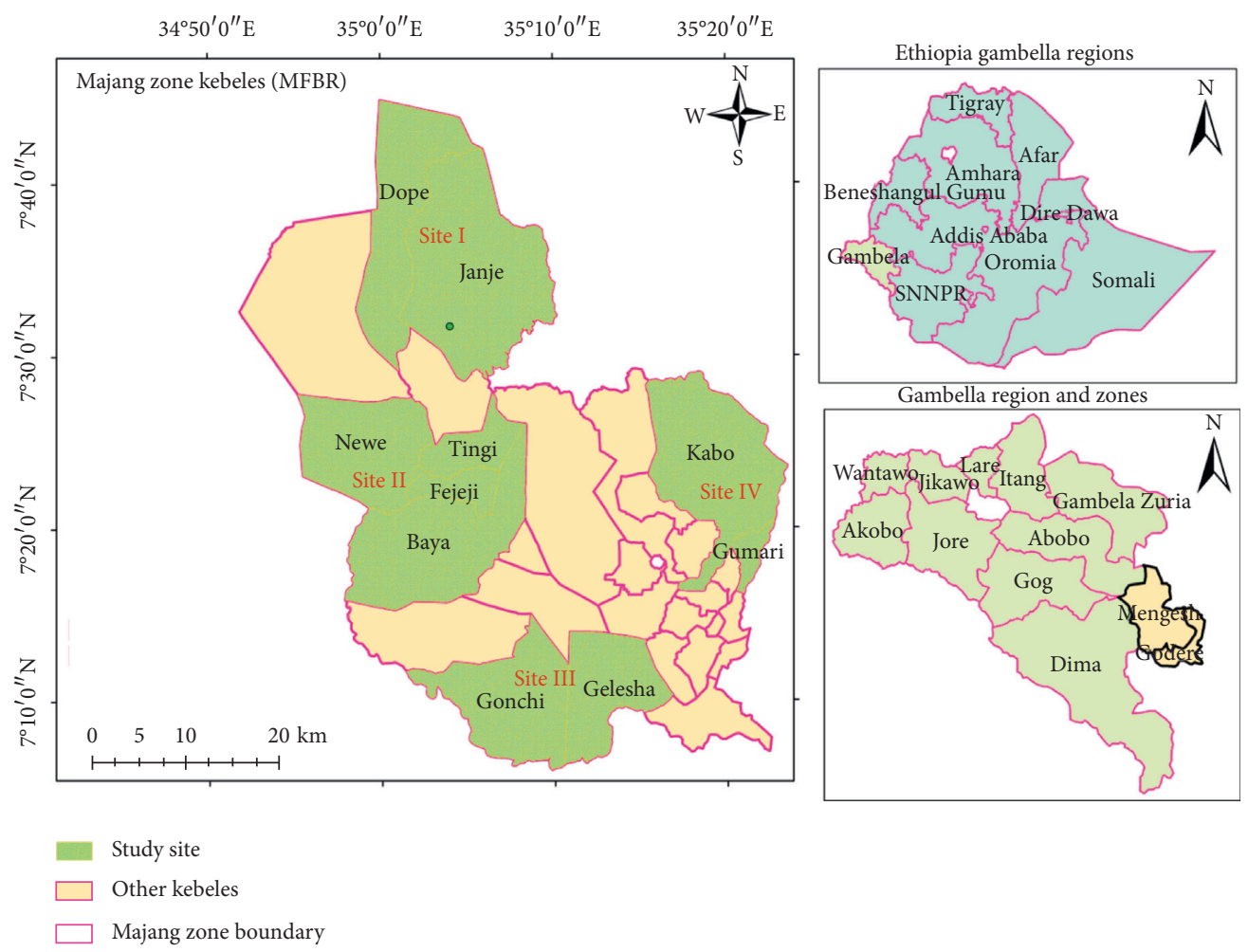

FIgURE 1: Location of the study area (Site I-IV).

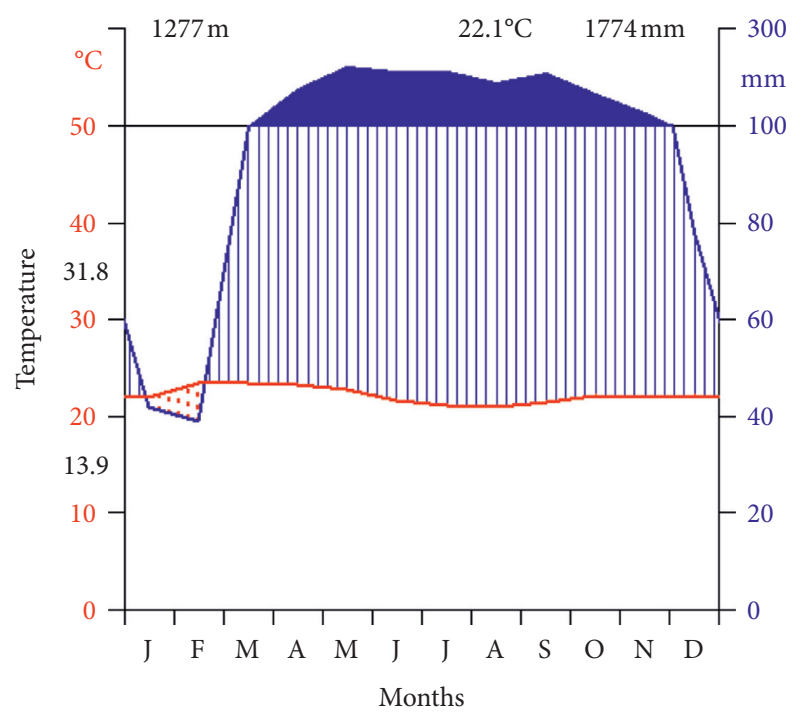

(a)

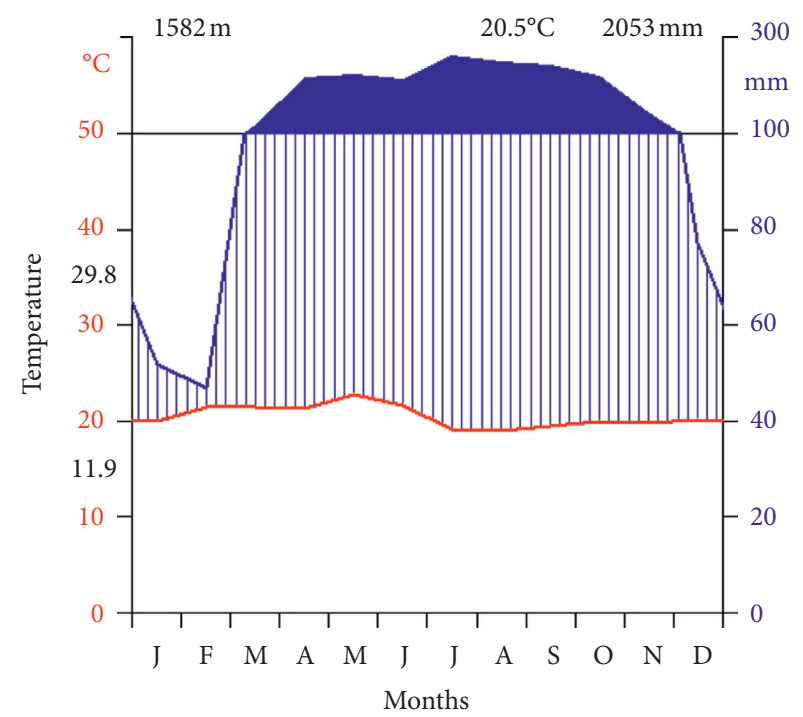

(b)

Figure 2: Mean annual temperature and rainfall recorded: (a) Tinishu Meti (1987-2017) and (b) Ermichi (1987-2017) metrological stations. Source: NMA (2020) for climatic data.

TABle 1: Area of land use/land change in MFBR.

\begin{tabular}{lccccr}
\hline \multirow{2}{*}{ Study period } & & \multicolumn{4}{c}{ Land use classes (ha) } \\
& Forestland & Farmland & Grassland & Settlement & Water body \\
\hline 1987 & $196,761.6$ & $30,791.8$ & $3,509.2$ & $2,050.4$ & 141.0 \\
2002 & $188,403.7$ & $36,902.4$ & $3,072.6$ & $4,734.3$ & 141.0 \\
2017 & $181,504.9$ & $40,554.8$ & $3,192.2$ & $7,861.1$ & $\mathbf{2 3 3 , 2 5 4}$ \\
Mean & 188890.1 & 36083 & 3258 & 4881.9 & $\mathbf{2 3 3 , 2 5 4}$ \\
\hline
\end{tabular}

Source: [19]. 
The systematic sampling design was adapted from [27] to collect vegetation. The studies were arranged in four sites considering altitudinal deference to represent Majang forest biosphere reserves: site I (Janje-Dope with an altitude of $<1200$ m.a.s.l.), site II (Newi-Kumi with an altitude between 1200 and 1500 m.a.s.l.), site III (Gelesha-Gubeti with an altitude between 1500 and 1800 m.a.s.l.), and site IV (Gumare-Kabo with an altitude of $>1800$ m.a.s.l.) (Table 2).

There are a total of 7-9 parallel transect lines, $2000 \mathrm{~m}$ $(2 \mathrm{~km})$ apart from each other. The sizes of quadrates were determined based on the growth forms of plants [27], i.e., $400 \mathrm{~m}^{2}$ for trees; $25 \mathrm{~m}^{2}$ for seedlings and saplings, shrubs, and lianas; and $1 \mathrm{~m}^{2}$ for herbs in a nested plot design. A total of 140 large quadrats were laid down, i.e., site I, 1-45 in "Janje-Dope"; site II, 46-85 in "Newi-Baya"; site III, 86-115 in "Gelesha-Gonchi"; and site IV, 116-140 in "Gumare-Kabo" of Majang forest biosphere reserves (Figure 3).

2.3. Data Collection. In this study, the shrub is defined as a woody plant that is multistemmed at the base of the plant, whereas a liana is any long-stemmed, woody vine that uses trees or other means for vertical support. Seedlings are defined as woody plants with a height less than $1.30 \mathrm{~m}$ and diameter of $<2.5 \mathrm{~cm}$; saplings as woody plants with a height of $>1.30 \mathrm{~m}$ and diameter at breast height $(\mathrm{DBH})$ of $2.5-5 \mathrm{~cm}$; and adult trees as plants with a $\mathrm{DBH}$ of $\geq 5 \mathrm{~cm}$ [28].

All tree species with diameters $(\mathrm{DBH})$ of $\geq 5 \mathrm{~cm}$ were counted and recorded. The $\mathrm{DBH}$, height, and crown cover of individuals of the species were measured using a diameter tape, clinometers, and meter tape, respectively. When the branching of multistemmed individuals occurred below the $\mathrm{DBH}$, the $\mathrm{DBH}$ of each stem was measured separately and a common diameter of all stems by summing uptake average diameter was developed. To determine the diversity and estimate the abundance of shrubs and lianas, subplots ( area $=25 \mathrm{~m}^{2}$ each) were established. Similarly, the identity of species and abundance of seedlings and saplings were counted and recorded in $25 \mathrm{~m}^{2}$ area. The cover-abundance of herbaceous was estimated in five subplots $\left(1 \mathrm{~m}^{2}\right)$ visually within the main plot in $400 \mathrm{~m}^{2}$. And then, cover-abundance of herbaceous from each plot was converted into 9 coverabundance scale classes: $1=(<0 . \%), \quad 2=(0.5-1.5 \%), \quad 3=$ $(1.5-3 \%), \quad 4=(3-5 \%), \quad 5=(5-12.5 \%), \quad 6=(12.5-25 \%), \quad 7=$ $(25-50 \%), 8=50-75 \%$, and $9=>75 \%$ cover [29].

The site factors such as elevation $(\mathrm{m})$ and slope (\%), harvesting index, and canopy openness were measured and documented. Elevation and slope were measured using the GPS and clinometer, respectively. Canopy openness was measured using the densitometer located at the centre of each plot, while harvesting index was measured by means counting the stumps individual which was an illegally logged tree inside the plot [30]. Stumps are a small part of a stem that remains after harvesting of trees reaching a minimum diameter of $\geq 5 \mathrm{~cm}$.

Plants were identified in the field, and for those difficult to identify in the field, specimens were collected, pressed, and identified in the National Herbarium (ETH) of Ethiopia.
The nomenclature of plants in this study follows those published in the Flora of Ethiopia as well as the Flora of Ethiopia and Eritrea [31, 32].

2.4. Data Analysis. The field data were compiled and arranged in an excel sheet, and the data such as stem density, relative density, frequency, relative frequency, dominance, relative dominance, important value index, and Jaccard's similarity coefficient (JSC) were analysed using the equations provided in Table 3.

For the sake of setting priority for conservation, all woody species encountered in the forest were grouped into five IVI classes based on their total IVI values according to the criteria developed by the Institute of Biodiversity Conservation and Research (IBCR). Species that receive lower IVI values need high conservation priority, while species that receive high IVI values need monitoring and management (Table 4) [38].

The regeneration pattern of woody species was assessed by employing a total count of seedlings (woody species of height $\leq 1.3 \mathrm{~cm}$ and $\mathrm{DBH} \leq 2.5 \mathrm{~cm}$ ) and saplings (woody species of height $>1.30$ and $\mathrm{DBH} \geq 2.5 \mathrm{~cm}$ ) within the main quadrates [39]. Pattern $1=$ If the regeneration results of woody species show seedlings $>$ sapling $>$ adults, "good regeneration". Pattern $2=$ if seedlings $>$ or $\leq$ saplings $\leq$ adults, "fair regeneration", and Pattern $3=$ if the woody species survive only in the sapling stages, "poor regeneration". Pattern $4=$ If a woody species is present only in the adult stage, it is considered as not regenerating ("not regenerated") [40].

Harvesting index was measured by means counting the stumps individual which was an illegally logged tree inside the plot and computed from the relative density of individual tree stump [30]. The stump relative density was computed as the sum of stump density divided by the total density (the sum of the logged stump and live individual tree).

The variation of basal area and density of seedlings, saplings, and mature trees of all woody species in response to altitude along with study sites and sampling plots were computed using ANOVA ( $\mathrm{R}$ statistical package). A correlation analysis was performed using the $\mathrm{R}$ statistical package to analyse the status of natural regeneration in response to site factors (elevation, slope, canopy openness, harvesting index, and herbaceous cover). Descriptive statistics such as tables and graphs were performed using the Microsoft Office Excel 2007 software.

\section{Results}

3.1. Species Composition. A total of 158 plant species (Appendix 1) belonging to 115 genera and 56 families were recorded and identified in the sample plots in the MFBR (Table 5). Of these, 80 species (51\%) were trees, 26 species (16\%) were shrubs, 19 species (12\%) were herbs, and 33 species $(21 \%)$ were lianas (Figure 4$)$. Moreover, the number of families and species were 43 (77), 45 (78), 44 (82), and 34 (84) in study sites I, II, III, and IV, respectively (Table 5).

The most dominant families recorded in the MFBR were Euphorbiaceae, Rubiaceae, and Moraceae; each represented 
TABLE 2: Locations and topographic characteristics of studied forests.

\begin{tabular}{|c|c|c|c|c|c|c|c|c|c|}
\hline $\begin{array}{l}\text { Study } \\
\text { site }\end{array}$ & $\begin{array}{c}\text { Area } \\
\text { (ha) }\end{array}$ & $\begin{array}{c}\text { Elevation } \\
(\mathrm{m})\end{array}$ & Aspects & Latitude & Longitude & $\begin{array}{l}\text { MAR } \\
(\mathrm{mm}) \\
\end{array}$ & $\begin{array}{c}\operatorname{Tmax} \\
\left({ }^{\circ} \mathrm{C}\right)\end{array}$ & $\begin{array}{l}\text { Tmin } \\
\left({ }^{\circ} \mathrm{C}\right)\end{array}$ & $\begin{array}{c}\text { Sample } \\
\text { plots }\end{array}$ \\
\hline Site I & $22,826.1$ & $1042 \pm 42.5$ & $\begin{array}{l}\text { NE, NW, SE, } \\
\text { W, E, SW }\end{array}$ & $7^{\circ} 40^{\prime} 00^{\prime \prime}-7^{\circ} 30^{\prime} 00^{\prime \prime}$ & $35^{\circ} 0^{\prime} 00^{\prime \prime}-35^{\circ} 10^{\prime} 00^{\prime \prime}$ & 1774 & 31.8 & 14.8 & 40 \\
\hline Site II & $25,220.5$ & $1365 \pm 24.6$ & S, E, NE, SE & $7^{\circ} 15^{\prime} 00^{\prime \prime}-7^{\circ} 26^{\prime} 00^{\prime \prime}$ & $34^{\circ} 30^{\prime} 00^{\prime \prime}-35^{\circ} 10^{\prime} 00^{\prime \prime}$ & 1774 & 31.8 & 14.8 & 45 \\
\hline Site III & 14,053 & $1635.8 \pm 24.6$ & $\begin{array}{c}\text { NW, S, NE, N, } \\
\text { SE }\end{array}$ & $7^{\circ} 05^{\prime} 00^{\prime \prime}-7^{\circ} 12^{\prime} 00^{\prime \prime}$ & $35^{\circ} 0^{\prime} 00^{\prime \prime}-35^{\circ} 15^{\prime} 00^{\prime \prime}$ & 1774 & 31.8 & 14.8 & 30 \\
\hline Site IV & $11,783.5$ & $2011.4 \pm 42.5$ & $\mathrm{~S}, \mathrm{~N}, \mathrm{NE}, \mathrm{NW}$ & $7^{\circ} 18^{\prime} 00^{\prime \prime}-7^{\circ} 28^{\prime} 00^{\prime \prime}$ & $35^{\circ} 15^{\prime} 00^{\prime \prime}-35^{\circ} 25^{\prime} 00^{\prime \prime}$ & 2053 & 29.8 & 12.8 & 25 \\
\hline
\end{tabular}

$\mathrm{MAR}=$ mean annual rainfall, Tmin = minimum temperature, Tmax = maximum temperature. Sites I, II, and III are found in the Tinishu Meti metrological station, while site IV is found in the Ermichi metrological station. Source: NMA (2020) for climatic data.

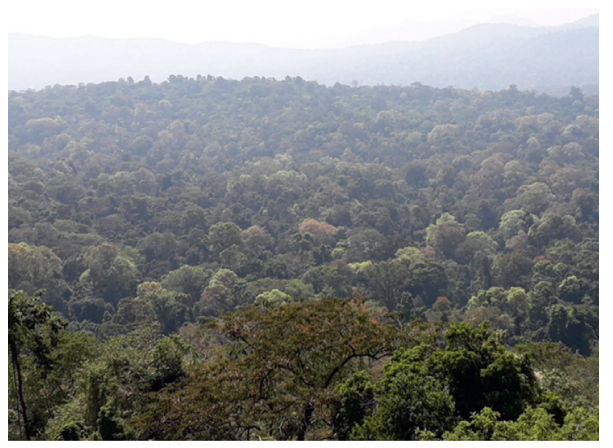

(a)

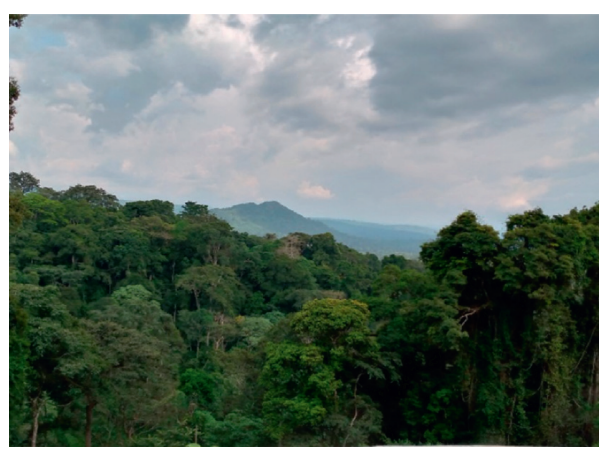

(c)

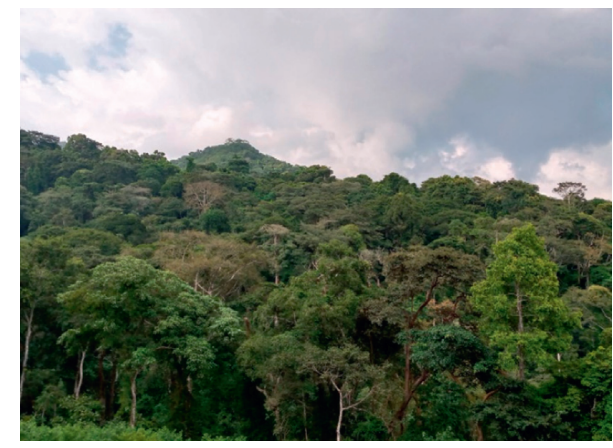

(b)

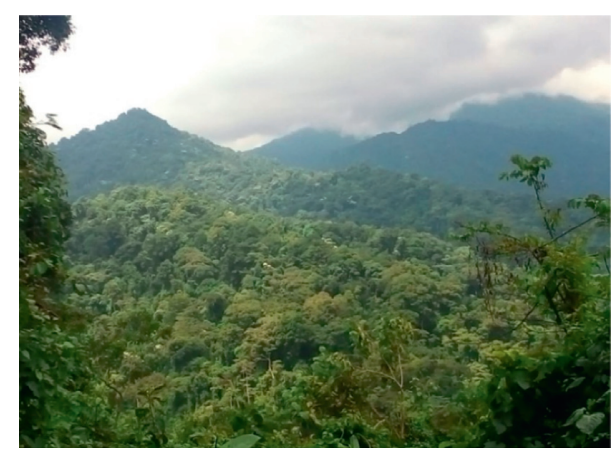

(d)

Figure 3: (Photo 1) Feature of the study sites. Source: Semegnew T (2020). (a) Site I (Janje-Dope). (b) Site II (Newi-Baya). (c) Site III (Gonchi-Gelesha). (d) Site IV (Gumare-Kabo).

TABLE 3: List of equations used for the calculation of vegetation parameters.

\begin{tabular}{lccc}
\hline Vegetation parameters & Equation & Equation no. & Reference \\
\hline Density & $\mathrm{D}=n / N$ & 1 & 2 \\
Relative density & $\mathrm{RD}=(n / N)^{*} 100$ & 3 & {$[33]$} \\
Frequency & $\mathrm{F}=(x / y)^{*} 100$ & 4 & {$[34,35]$} \\
Relative frequency & $\mathrm{RF}=\left(\mathrm{F} i / \sum_{i=1}^{s}(\mathrm{~F} i)\right)^{*} 100$ & 5 & {$[33]$} \\
Basal area & $\mathrm{BA}=\left(\pi \mathrm{D} b H^{2} / 4\right)$ & 6 & {$[34,35]$} \\
Relative basal area & $\mathrm{BA}=\mathrm{B} i / \sum_{i=1}^{s} \mathrm{Bi}$ & 8 & {$[36]$} \\
Dominance & $\mathrm{Do}=\sum_{i=1}^{s} \mathrm{Bi} / \mathrm{Bi}$ & {$[36]$} \\
Relative dominance & $\mathrm{Do}=\mathrm{D} i / \sum_{i=1}^{s} \mathrm{D} i$ & {$[36]$} & {$[36]$} \\
Important value index (IVI) & $\mathrm{IVI}=\mathrm{RD}+\mathrm{RF}+\mathrm{RD}$ & 10 & {$[33,35,36]$} \\
Jaccard's similarity coefficient (JSC) & $\mathrm{S} j=a /(a+b+c)$ & {$[37]$} \\
\hline
\end{tabular}

$a=$ number of tree species common to sites A and $\mathrm{B} ; b=$ number of tree species recorded only site A; $c=$ number of tree species recorded only in site $\mathrm{B} ; n$ : total number of individuals of the species; $N$ : total number of individuals of all the species; $x$ : total number of quadrats in which the species occurs; $y$ : total number of quadrats studied; Fi: frequency of one species; Bi: basal area of one species; Di: dominance of one species. 
TABLE 4: Criteria for setting IVI classes and conservation priority based on IVI values.

\begin{tabular}{lccc}
\hline IVI values \% & IVI class & Priority class & Required intervention \\
\hline$>30$ & 1 & 5 & Monitoring and management \\
$20.1-30$ & 2 & 4 & Monitoring and management \\
$10.1-20$ & 3 & 3 & Conservation/restoration \\
$1-10$ & 4 & 2 & Conservation/restoration \\
$<1$ & 5 & 1 & Conservation/restoration \\
\hline
\end{tabular}

Source: Institution of Biological Conservation Research [38].

TABLE 5: Stand characteristics of woody species and analysis of variance in four study sites.

\begin{tabular}{|c|c|c|c|c|}
\hline Forest characteristics & Site I & Site II & Site III & Site IV \\
\hline No. of plots (n) & 45 & 40 & 30 & 25 \\
\hline No. of families & 43 & 45 & 44 & 34 \\
\hline No. of species & 77 & 78 & 82 & 84 \\
\hline No of genera & 68 & 72 & 74 & 60 \\
\hline $\mathrm{D}\left(\right.$ stem ha $\left.^{-1}\right)$ & $1232^{* a}$ & $1318^{* b}$ & $1478^{* \mathrm{c}}$ & $1309^{*} \mathrm{~d}$ \\
\hline $\mathrm{BA}\left(\mathrm{m}^{2} \mathrm{ha}^{-1}\right)$ & $54.8^{* \mathrm{a}}$ & $56.8^{* \mathrm{~b}}$ & $67.1^{* c}$ & $76.3^{* d}$ \\
\hline Harvesting index (mean \pm standard error \%) & $134 \pm 4.2$ & $158 \pm 4.9$ & $164 \pm 6.1$ & $176 \pm 6.5$ \\
\hline Herbaceous cover (mean \pm standard error \%) & $165 \pm 5.2$ & $182 \pm 5.4$ & $182 \pm 6.7$ & $147 \pm 5.4$ \\
\hline
\end{tabular}

*Significant at $P<0.05$; different letters indicate significant differences between sites. Site I = Janje-Dope, Site II = Newi-Baya, Site III = Gonchi-Gelesha, and Site IV = Gumare-Kabo.

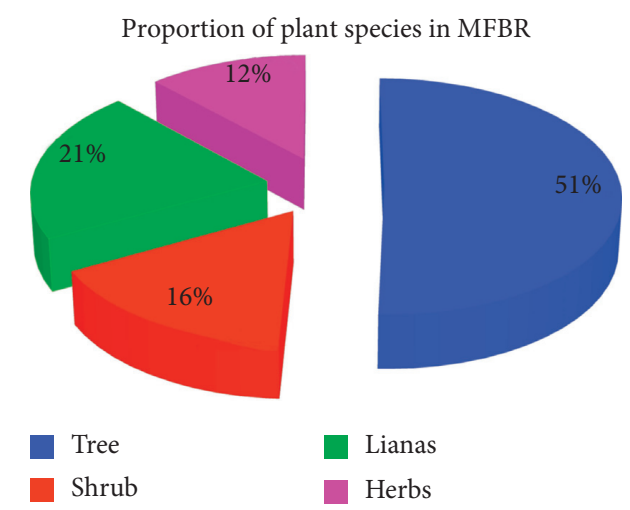

Figure 4: Proportion of plant species of MFBR in different habitats.

by 13 species $(7.4 \%)$ and 9 genera $(7.8 \%), 12$ species $(6.8 \%)$ and 8 genera $(7 \%)$, and 10 species $(5.7 \%)$ and 4 genera (3.5\%), respectively, of total floristic composition. The genus Ficus, Asplenium, Dracaena, Vernonia, and Albizia were represented by seven, six, six, five, and four species, respectively, whereas Justicia, Pseuderanthemum, Alangium, Polyscias, Schefflera, Tacazzea, Combretum, Macaranga, Millettia, Olea, Pittosporum, Leptaspis, Rothmannia, Psychotria, Fagaropsis, Vepris, and Allophylus were represented by 2 species each, and the rest genera contained a single species each (Appendix 1).

3.2. Similarity in Species Composition. The similarities in species composition were ranged from $2 \%$ to $71 \%$ between study sites in Majang forest biosphere reserves. There is dissimilarity in tree species composition between sites I and IV (2\%), sites II and IV (4\%), and sites III and IV (2\%). The highest similarity species composition of the tree was $71 \%$ between sites I and II, whereas the lowest similarity was $2 \%$ between sites I and IV as well as between sites III and IV. Similarly, species composition similarity between site I and site III as well as between site II and site III was $61 \%$ and $63 \%$, respectively (Table 6).

\subsection{Vegetation Structure}

3.3.1. Density of Woody Species. Woody species densities in Majang forest biosphere reserves were analysed, and the result was described as a number of stems per hectare. The overall density of woody species in the study area was 1350 individuals $(\mathrm{DBH}>5 \mathrm{~m})$ per hectare. There were a total of 80 woody species in all density classes. The species were classified into 6 density classes, $\mathrm{A}-\mathrm{F}$, as follows: $\mathrm{A} \leq 1$; $\mathrm{B}=1.01-10 ; \quad C=10.1-20 ; \quad \mathrm{D}=20.1-35 ; \quad \mathrm{E}=35.01-50 ;$ and $\mathrm{F}=>50$. Based on density classes, 21 (B), 32 (C), 14 (D), 7 (E), and $6(\mathrm{~F})$ species exist in each density class respectively, while no species exist in density class A (Figure 5). The highest tree density was in site III (1478 stems ha ${ }^{-1}$ ) (Table 5 
TABle 6: Species composition similarity among study sites.

\begin{tabular}{lcccc}
\hline \multirow{2}{*}{ Study sites } & \multicolumn{4}{c}{ Jaccard's similarity coefficient (SJ) } \\
& Site I & Site II & Site III & Site IV \\
\hline Site I & & & & \\
Site II & 0.71 & & & \\
Site III & 0.61 & 0.63 & & \\
Site IV & 0.02 & 0.04 & 0.02 & \\
\hline
\end{tabular}

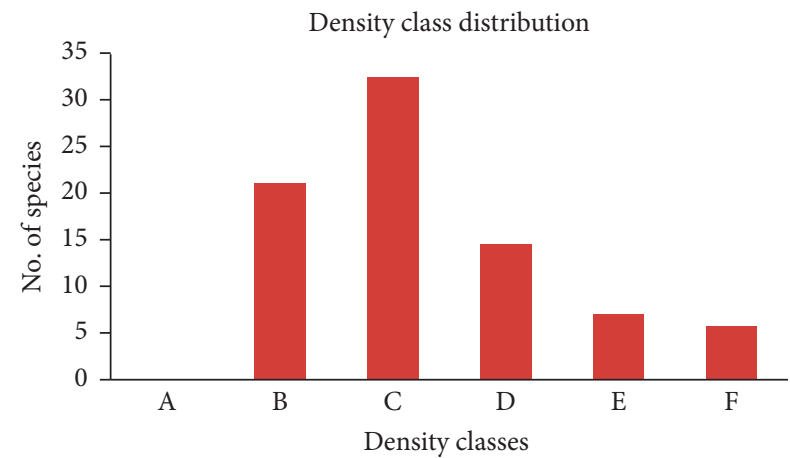

FIgURE 5: Density class distribution of woody species in MFBR.

and Appendix 5), while the lowest tree density ha ${ }^{-1}$ was in site I (1232 ha $\mathrm{ha}^{-1}$ ) (Table 5 and Appendix 3). There was a significant difference in density $\mathrm{ha}^{-1}$ between study sites ( $\mathrm{F}=156.5, \mathrm{~d} f=56.23, \quad P=0.000003)$. Likewise, the tree densities were significantly different between site I and site II $(\mathrm{F}=101.1, \quad P=0.0007)$, site II and site III $(\mathrm{F}=26.16$ $P=0.0087)$, and site III and site IV $(\mathrm{F}=176.4, P=0.0012)$. The species that showed the highest density were Celtis zenkeri (141 ha $\left.\mathrm{ha}^{-1}\right)$, Pouteria altissima $\left(102 \mathrm{ha}^{-1}\right)$, Blighia unijugata $\left(115 \mathrm{ha}^{-1}\right)$, and Cyathea manniana $\left(96.25 \mathrm{ha}^{-1}\right)$ in sites I, II, III, and IV, respectively (Table 7). The species that showed the least density were Albizia grandibracteata $\left(5 \mathrm{ha}^{-1}\right)$, Teclea nobilis $\left(2 \mathrm{ha}^{-1}\right)$, Castanea sativa $\left(3.75 \mathrm{ha}^{-1}\right)$, and Bersama abyssinica $\left(10 \mathrm{ha}^{-1}\right)$ in sites I, II, III, and IV, respectively (Appendixes 13-16).

Furthermore, the density of trees species with DBHs $5-10 \mathrm{~cm}, 10.1-20 \mathrm{~cm}$, and $>20$ were $282.2(20.9 \%), 617.50$ (20.9\%), and 450.3 (33.4\%) individuals per hectare, respectively. Accordingly, the ratio of individuals between DBH classes $10.1-20 \mathrm{~cm}$ (a) to $\mathrm{DBH}>20 \mathrm{~cm}$ (b) was 1.4 in the study area (Table 8 ).

3.3.2. Frequency of Woody Species. Based on their total frequency percentage, the species were grouped in the following five frequency classes: $A=0-20 \% ; \quad B=21-40 \%$; $\mathrm{C}=41-60 \% ; \mathrm{D}=61-80$; and $\mathrm{E}=81-100 \%$. In this study, 24 , $16,10,5$, and 2 species were recorded in frequency classes $A$, B, C, D, and E, respectively (Figure 6). Dracaena afromontana was the most frequent woody species in the MFBR occurring in $90 \%$ of the sample plots followed by Celtis zenkeri (65\%), Pouteria altissima (62.5\%), Triumfetta tomentosa (45\%), Polyscias fulva (45\%), Schefflera abyssinica (45\%), and Pouteria adolfi-friederici (45\%) (Table 7, Appendixes 2-6). The least frequent woody species in the MFBR occurring below $5 \%$ of the sampled plots were
Rothmannia urcelliformis, Bersama abysinica, Ficus thonningii, Ficus exasperata, Psychotria orophila, Vernonia hochstetteri, and Celtis toka (Appendixes 2-6). The frequency distribution of woody species in the MFBR shows that the number of tree species found in the first frequency classes is higher and gradually decreases towards higher frequency classes (Figure 6). The frequency values of the woody species ranged from $0.1 \%$ to $99 \%$ in the MFBR.

In the site I, the frequency ranges from $4 \%$ to $88 \%$, and the most frequent woody species were Celtis zenkeri $(88 \%)$, Pouteria altissima (76\%), Diospyros abyssinica (72\%), and Antiaris toxicaria (72\%); and the least frequent woody species were Mimusops lanceolata (13\%), Combretum molle (10\%), and Albizia grandibracteata (5\%) (Table 7, Appendix 3).

In site II, the frequency ranges from $4 \%$ to $100 \%$, and the most frequent woody species are Pouteria altissima (100\%), Celtis zenkeri (84\%), Lannea welwitschii (68\%), and Lecaniodiscus fraxinifolius (64\%), while the least frequent woody species were Tapura guianensis (8\%), Teclea nobilis (8\%), Buddleja polystachya (4\%), and Dombeya torrida (4\%) (Table 7, Appendix 4). Celtis zenkeri (95\%), Blighia unijugata (90\%, Pouteria alnifolia (75), and Pouteria altissima (70\%) were the most frequent woody species, while Apodytes dimidiata (5\%), Deinbollia kilimandschrica (5\%), and Plumbago auriculata (0.1\%) were rarely occurred species in study site III (Table 7, Appendix 5). In site IV, Dracaena afromontana (100\%), Cyathea manniana (100\%), and Vernonia auriculifera (85\%) were the highest frequency value, while Phoenix reclinata (25\%), Coffea arabica (20\%), and Psychotria orophila (15\%) exhibited the lowest frequency value.

3.3.3. Basal Area. The basal area value ranges from 54.8 to $76.3 \mathrm{~m}^{2} \cdot \mathrm{ha}^{-1}$ from the study site I-IV, respectively. The lowest and highest basal area values were in the study sites I and IV, respectively (Table 5 and Appendixes 9-12). The mean basal area of the four study sites was $63.6 \pm 5.4 \mathrm{~m}^{2} \cdot \mathrm{ha}^{-1}$. The ANOVA result indicated that there was a significant difference in the basal area $(P<0.05)$ between study sites $(\mathrm{F}=37.5, \mathrm{~d} f=53.44, P=0.000003)$. Similarly, the basal area was significantly different $(P<0.05)$ between site I and site II $(\mathrm{F}=6.123, P=0.01912)$, site II and site III $(\mathrm{F}=106.4, P=0.0000081)$, and site III and site IV $(\mathrm{F}=107.7, P=0.0000075)$ (Table 5).

The total dominance was $54.5 \mathrm{~m}^{2} \cdot \mathrm{ha}^{-1}$ in site $\mathrm{I}$, the highest $4.25 \mathrm{~m}^{2} \cdot \mathrm{ha}^{-1}(7.79 \%)$ and the lowest basal area $0.05 \mathrm{~m}^{2} \cdot \mathrm{ha}^{-1}(0.09 \%)$ were contributed by Celtis zenkeri and Teclea nobilis, respectively (Appendix 9). About $28.92 \mathrm{~m}^{2} \cdot \mathrm{ha}^{-1}(53.2 \%)$ of the total basal area was covered by ten large-sized tree species in study site I (Table 9). Cordia africana exhibited low density and high basal area due to its maximum average $\mathrm{DBH}$ value. A total of $25.62 \mathrm{~m}^{2} \cdot \mathrm{h}^{-1}$ (46.98\%) was contributed by 27 species in study site I (Appendix 9).

In study site II, the total basal area was $56.8 \mathrm{~m}^{2} \cdot \mathrm{ha}^{-1}$ with the highest $4.03 \mathrm{~m}^{2} \cdot \mathrm{ha}^{-1}(7.09 \%)$ and the lowest basal area $0.04 \mathrm{~m}^{2} \cdot \mathrm{ha}^{-1}(0.07 \%)$ were contributed by $P$. altissima and P. fulva, respectively (Table 9 and Appendix 9). About 
TABLE 7: The top ten species with the highest IVI value in all the sites of MFBR.

\begin{tabular}{|c|c|c|c|c|c|c|c|c|}
\hline Species scientific name & $\mathrm{D}$ & DO & Fr & $\mathrm{RD}$ & RDO & RFr & IVI & $\mathrm{CPC}$ \\
\hline \multicolumn{9}{|l|}{ All sites } \\
\hline Celtis zenkeri (A.Rich) Wedd & 81.3 & 34.9 & 65.0 & 6.1 & 0.3 & 3.37 & 9.8 & 2 \\
\hline Pouteria altissima (A.Chev.) Baehni & 64.1 & 38.2 & 62.5 & 4.8 & 0.3 & 3.24 & 8.4 & 2 \\
\hline Blighia unijugata Bak. & 45.6 & 44.7 & 40.0 & 0.2 & 7.8 & 0.19 & 8.2 & 2 \\
\hline Lecaniodiscus fraxinifolius Bak. & 59.4 & 55.0 & 38.8 & 4.4 & 0.5 & 2.01 & 6.9 & 2 \\
\hline Dracaena afromontana Mildbr. & 22.5 & 46.9 & 90.0 & 1.7 & 0.4 & 4.67 & 6.8 & 2 \\
\hline Antiaris toxicaria Resch & 48.4 & 55.0 & 41.3 & 3.6 & 0.5 & 2.14 & 6.2 & 2 \\
\hline Baphia abyssinica Brummit & 48.8 & 55.0 & 33.8 & 3.6 & 0.5 & 1.75 & 5.9 & 2 \\
\hline Celtis toka (Forssk.) Hepper \& Wood & 32.5 & 879.3 & 3.8 & 3.4 & 0.4 & 2.08 & 5.9 & 2 \\
\hline Schefflera abyssinica (Hochst. ex A. Rich. & 11.3 & 239.1 & 45.0 & 0.8 & 2.1 & 2.33 & 5.3 & 2 \\
\hline Pouteria adolfi-friederici (Engl.) Baehni & 11.3 & 68.7 & 41.3 & 2.4 & 0.6 & 2.14 & 5.2 & 2 \\
\hline \multicolumn{9}{|l|}{ Site I } \\
\hline Celtis zenkeri (A.Rich) Wedd & 141 & 14.1 & 88 & 10.7 & 0.74 & 6.9 & 18.3 & 3 \\
\hline Diospyros abyssinica (Hiern) F. White & 86 & 24.6 & 72 & 6.5 & 1.29 & 5.6 & 13.4 & 3 \\
\hline Antiaris toxicaria Resch & 88 & 16.9 & 72 & 6.7 & 0.89 & 5.6 & 13.2 & 3 \\
\hline Pouteria altissima (A.Chev.) Baehni & 81 & 14.9 & 76 & 6.1 & 0.78 & 5.9 & 12.8 & 3 \\
\hline Morus mesozygia Stapf. & 53 & 53.7 & 68 & 4.0 & 2.81 & 5.3 & 12.1 & 3 \\
\hline Teclea nobilis Del. & 18 & 157.6 & 32 & 1.4 & 8.26 & 2.5 & 12.1 & 3 \\
\hline Lecaniodiscus fraxinifolius Bak. & 81 & 20.2 & 60 & 6.1 & 1.06 & 4.7 & 11.9 & 3 \\
\hline Celtis toka (Forssk.) Hepper \& Wood & 60 & 24.7 & 68 & 4.6 & 1.29 & 5.3 & 11.1 & 3 \\
\hline Blighia unijugata Bak. & 57 & 21.2 & 56 & 4.3 & 1.11 & 4.4 & 9.8 & 2 \\
\hline Lannea welwitschii (Hiern) Engl. & 33 & 59.8 & 44 & 2.5 & 3.14 & 3.4 & 9.0 & 2 \\
\hline \multicolumn{9}{|l|}{ Site II } \\
\hline Pouteria altissima (A.Chev.) Baehni & 102 & 14.0 & 100 & 8.3 & 3.07 & 7.3 & 18.6 & 3 \\
\hline Celtis zenkeri (A.Rich) Wedd & 87 & 18.1 & 84 & 7.1 & 3.14 & 6.1 & 16.3 & 3 \\
\hline Lecaniodiscus fraxinifolius Bak. & 100 & 20.8 & 64 & 8.1 & 3.52 & 4.7 & 16.3 & 3 \\
\hline Baphia abyssinica Brummit & 69 & 18.2 & 48 & 5.6 & 2.90 & 3.5 & 12.0 & 3 \\
\hline Cordia africana Lam. & 59 & 14.6 & 60 & 4.8 & 2.61 & 4.4 & 11.8 & 3 \\
\hline Antiaris toxicaria Resch & 61 & 25.3 & 56 & 5.0 & 2.59 & 4.1 & 11.6 & 3 \\
\hline Ficus exasperata Vahl & 37 & 42.1 & 44 & 3.0 & 5.28 & 3.2 & 11.5 & 3 \\
\hline Celtis toka (Forssk.) Hepper \& Wood & 29 & 42.8 & 48 & 2.4 & 5.14 & 3.5 & 11.0 & 3 \\
\hline Ritchiea albersii Gilg & 42 & 55.9 & 56 & 3.4 & 3.43 & 4.1 & 10.9 & 3 \\
\hline Lannea welwitschii (Hiern) Engl. & 43 & 20.0 & 68 & 3.5 & 1.05 & 4.9 & 9.5 & 2 \\
\hline \multicolumn{9}{|l|}{ Site III } \\
\hline Blighia unijugata Bak. & 115 & 32.6 & 90 & 7.8 & 1.02 & 5.3 & 14.10 & 3 \\
\hline Celtis zenkeri (A.Rich) Wedd & 93.7 & 18.9 & 95 & 6.3 & 0.59 & 5.6 & 12.53 & 3 \\
\hline Pouteria alnifolia (Bak.) Roberty & 71.2 & 97.7 & 75 & 4.8 & 3.06 & 4.4 & 12.30 & 3 \\
\hline Pouteria altissima (A.Chev.) Baehni & 77.5 & 25.0 & 70 & 5.2 & 0.78 & 4.1 & 10.15 & 3 \\
\hline Baphia abyssinica Brummit & 80 & 21.2 & 60 & 5.4 & 0.66 & 3.5 & 9.61 & 2 \\
\hline Margaritaria discoidea (Baill.) Webster & 48.7 & 41.3 & 65 & 3.3 & 1.29 & 3.8 & 8.42 & 2 \\
\hline Antiaris toxicaria Resch & 57.5 & 34.1 & 45 & 3.9 & 1.07 & 2.6 & 7.61 & 2 \\
\hline Trichilia prieuriana A.Juss & 53.7 & 41.3 & 45 & 3.6 & 1.29 & 2.6 & 7.58 & 2 \\
\hline Combretum molle R.Br. ex G.Don & 53.7 & 29.7 & 50 & 3.6 & 0.93 & 2.9 & 7.51 & 2 \\
\hline Lannea welwitschii (Hiern) Engl. & 47.5 & 47.9 & 45 & 3.2 & 1.50 & 2.6 & 7.36 & 2 \\
\hline \multicolumn{9}{|l|}{ Site IV } \\
\hline Cyathea manniana Hook & 96.3 & 27.2 & 100 & 11.2 & 1.1 & 4.0 & 16.3 & 3 \\
\hline Dracaena afromontana Mildbr. & 90.0 & 19.2 & 100 & 10.5 & 0.8 & 4.0 & 15.3 & 3 \\
\hline Trilepisium madagascariense DC & 71.3 & 23.4 & 65 & 6.8 & 1.0 & 2.6 & 10.4 & 3 \\
\hline Allophylus abyssinicus (Hochst.) Radlk. & 45.0 & 24.8 & 80 & 5.5 & 1.0 & 3.2 & 9.7 & 2 \\
\hline Pouteria adolfi-friederici (Engl.) Baehni & 45.0 & 97.2 & 80 & 2.2 & 4.1 & 3.2 & 9.5 & 2 \\
\hline Vernonia auriculifera Hiern & 43.8 & 61.2 & 85 & 2.7 & 2.6 & 3.4 & 8.7 & 2 \\
\hline Schefflera abyssinica (Hochst. ex A.Rich.) & 67.5 & 59.3 & 40 & 4.4 & 2.5 & 1.6 & 8.5 & 2 \\
\hline Schefflera myriantha (Bak.) Drake & 45.0 & 77.5 & 60 & 2.7 & 3.3 & 2.4 & 8.4 & 2 \\
\hline Ilex mitis (L.) Radlk. & 40.0 & 46.9 & 80 & 2.6 & 2.0 & 3.2 & 7.8 & 2 \\
\hline Galiniera saxifraga (Hochst.) Bridson & 35.0 & 53.3 & 75 & 2.5 & 2.2 & 3.0 & 7.8 & 2 \\
\hline
\end{tabular}

$\mathrm{D}=$ density, $\mathrm{DO}=$ dominance, $\mathrm{Fr}=$ frequency, $\mathrm{RD}=$ relative density, $\mathrm{RDO}=$ relative dominance, $\mathrm{RFr}=$ relative frequency, $\mathrm{IVI}=$ importance value index, and $\mathrm{CPC}=$ conservation priority class. 
TABLE 8: Density of tree species by DBH classes in MFBR.

\begin{tabular}{lccc}
\hline DBH $(\mathrm{cm})$ & No. of individuals $\left(\right.$ ha $\left.^{-1}\right)$ & Percentage (\%) & Ratio a to b \\
\hline $5-10$ & 282.19 & 20.9 \\
$10.1-20($ a) & 617.50 & 45.7 \\
$>20(\mathrm{~b})$ & 450.3 & 33.4 \\
& $\mathbf{1 3 5 0}$ & $\mathbf{1 0 0 . 0}$ \\
\hline
\end{tabular}

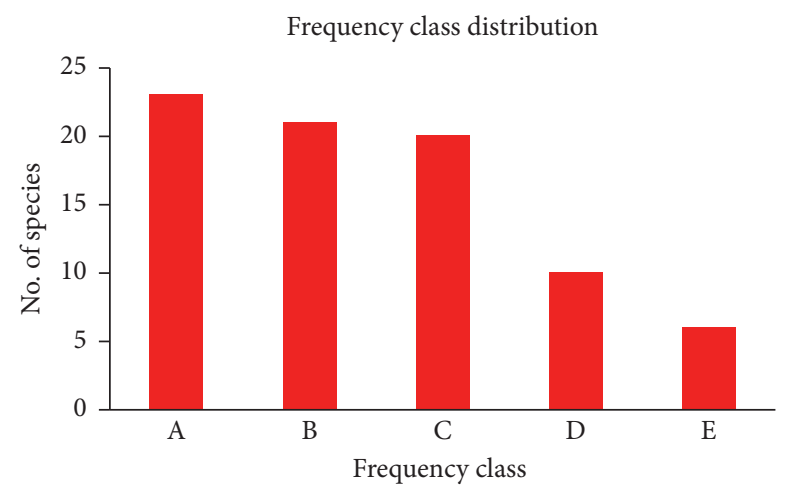

FIgURE 6: Frequency class distribution of woody species.

TABLE 9: Dominant trees with their BA and percentage in all the sites of MFBR.

\begin{tabular}{|c|c|c|c|c|}
\hline Scientific name & TD & Average DBH & $\mathrm{BA}\left(\mathrm{m}^{2} / \mathrm{ha}\right)$ & $\% \mathrm{BA}$ \\
\hline \multicolumn{5}{|l|}{ Site I } \\
\hline Celtis zenkeri (A.Rich.) Wedd & 141 & 20.5 & 4.25 & 7.79 \\
\hline Pouteria altissima (A.Chev.) Baehni & 81 & 27 & 3.87 & 7.09 \\
\hline Cordia africana Lam. & 57 & 44.5 & 3.21 & 5.88 \\
\hline Antiaris toxicaria Resch & 88 & 16.6 & 3.01 & 5.52 \\
\hline Blighia unijugata Bak. & 57 & 19 & 2.69 & 4.93 \\
\hline Lecaniodiscus fraxinifolius Bak. & 81 & 15 & 2.61 & 4.78 \\
\hline Baphia abyssinica Brummit & 46 & 20.5 & 2.57 & 4.71 \\
\hline Celtis toka (Forssk.) Hepper \& Wood & 60 & 15.5 & 2.32 & 4.25 \\
\hline Diospyros abyssinica (Hiern) F. White & 86 & 16.7 & 2.23 & 4.09 \\
\hline Mimusops lanceolata A.DC & 13 & 23.2 & 2.16 & 3.96 \\
\hline Total & 710 & 218.5 & 28.92 & 53.0 \\
\hline \multicolumn{5}{|l|}{ Site II } \\
\hline Pouteria altissima (A.Chev.) Baehni & 102 & 27 & 4.03 & 7.09 \\
\hline Cordia africana Lam. & 59 & 44.5 & 3.87 & 6.81 \\
\hline Celtis zenkeri (A.Rich.) Wedd & 87 & 20.5 & 3.12 & 5.49 \\
\hline Baphia abyssinica Brummit & 69 & 20.5 & 3.10 & 5.46 \\
\hline Lannea welwitschii (Hiern) Engl. & 43 & 28 & 2.82 & 4.96 \\
\hline Lecaniodiscus fraxinifolius Bak. & 100 & 15 & 2.71 & 4.77 \\
\hline Blighia unijugata Bak. & 31 & 19 & 2.69 & 4.73 \\
\hline Trichilia prieuriana A.Juss. & 28 & 20 & 2.51 & 4.42 \\
\hline Grewia mollis A.Juss. & 32 & 25.8 & 2.35 & 4.14 \\
\hline Antiaris toxicaria Resch & 61 & 16.6 & 2.23 & 3.92 \\
\hline Total & 612 & 236.9 & 29.43 & 51.79 \\
\hline \multicolumn{5}{|l|}{ Site III } \\
\hline Celtis zenkeri (A.Rich) Wedd & 93.75 & 20.5 & 3.76 & 5.61 \\
\hline Pouteria altissima (A.Chev.) Baehni & 77.5 & 27 & 3.44 & 5.14 \\
\hline Celtis toka (Forssk.) Hepper \& Wood & 42.5 & 15.5 & 3.38 & 5.04 \\
\hline Baphia abyssinica Brummit & 80 & 20.5 & 3.30 & 4.92 \\
\hline Blighia unijugata Bak. & 115 & 19 & 2.95 & 4.40 \\
\hline Cordia africana Lam. & 22.5 & 44.5 & 2.80 & 4.18 \\
\hline Lecaniodiscus fraxinifolius Bak. & 58.75 & 15 & 2.74 & 4.09 \\
\hline Ficus mucuso (Ficatho) & 31.25 & 27.5 & 2.70 & 4.03 \\
\hline Diospyros abyssinica (Hiern) F. White & 42.5 & 16.7 & 2.66 & 3.96 \\
\hline
\end{tabular}


TABle 9: Continued.

\begin{tabular}{|c|c|c|c|c|}
\hline Scientific name & TD & Average DBH & $\mathrm{BA}\left(\mathrm{m}^{2} / \mathrm{ha}\right)$ & $\% \mathrm{BA}$ \\
\hline Combretum molle R.Br. ex G.Don & 53.75 & 31 & 2.34 & 3.49 \\
\hline Total & 617.5 & 237.2 & 30.07 & 44.86 \\
\hline \multicolumn{5}{|l|}{ Site IV } \\
\hline Dracaena afromontana Mildbr. & 72 & 25 & 3.97 & 5.21 \\
\hline Cordia africana Lam. & 16 & 14 & 3.46 & 4.54 \\
\hline Galiniera saxifraga (Hochst.) Bridson & 52 & 18 & 3.36 & 4.41 \\
\hline Ficus sur Forssk. & 19 & 17 & 3.27 & 4.28 \\
\hline Trilepisium madagascariense DC & 57 & 17 & 3.27 & 4.28 \\
\hline Allophylus abyssinicus (Hochst.) Radlk & 36 & 18 & 3.08 & 4.04 \\
\hline Cyathea manniana Hook & 77 & 21 & 2.80 & 3.68 \\
\hline Schefflera abyssinica (Hochst. ex A.Rich.) Harms & 54 & 18 & 2.06 & 2.70 \\
\hline Albizia gummifera (J.F.Gmel.) C.A.Sm. & 29 & 16 & 2.01 & 2.64 \\
\hline Dracaena afromontana Mildbr. & 35 & 16 & 2.01 & 2.64 \\
\hline Total & 447 & 180 & 29.29 & 38.42 \\
\hline
\end{tabular}

$\mathrm{BA}=$ basal area, $\mathrm{MFBR}=$ Majang Forest Biosphere Reserve, and $\mathrm{TD}=$ tree density.

$29.43 \mathrm{~m}^{2} \cdot \mathrm{ha}^{-1}(51.8 \%)$ of the total basal area was covered by ten large-sized tree species in study site II. C. africana exhibited low density and high basal area due to its maximum average DBH value (Table 9). A total of $27.39 \mathrm{~m}^{2} \cdot \mathrm{h}^{-1}$ (48.2\%) was contributed by 31 species in study site I (Appendix 10).

In study site III, the total basal area was $67.1 \mathrm{~m}^{2} \cdot \mathrm{ha}^{-1}$, the highest $3.76 \mathrm{~m}^{2} \cdot \mathrm{ha}^{-1}(7.09 \%)$ and the lowest basal area $0.07 \mathrm{~m}^{2} \cdot \mathrm{ha}^{-1}(0.11 \%)$ were exhibited by $C$. zenkeri and Castanea sativa, respectively (Table 9 and Appendix 11). About $30.07 \mathrm{~m}^{2} \cdot \mathrm{ha}^{-1}(44.9 \%)$ of the total basal area was covered by ten large-sized tree species in study site III. C. africana exhibited low density and high basal area due to its maximum average $\mathrm{DBH}$ value (Table 9). A total of $36.96 \mathrm{~m}^{2} \cdot \mathrm{h}^{-1}(55.14 \%)$ was contributed by 36 species in study site I (Appendix 11).

Similarly, in study site IV, the total basal area was $76.3 \mathrm{~m}^{2} \cdot \mathrm{ha}^{-1}$, the highest $3.97 \mathrm{~m}^{2} \cdot \mathrm{ha}^{-1}(5.21 \%)$ and the lowest basal area $0.64 \mathrm{~m}^{2} \cdot \mathrm{ha}^{-1}(0.83 \%)$ were contributed by D. afromontana and B. abyssinica, respectively (Table 9 and Appendix 12). About $29.29 \mathrm{~m}^{2} \cdot \mathrm{ha}^{-1}(38.42 \%)$ of the total basal area was covered by ten large-sized tree species in study site III. C. africana exhibited low density and high basal area due to its maximum average $\mathrm{DBH}$ value (Table 9). A total of $46.96 \mathrm{~m}^{2} \cdot \mathrm{h}^{-1}(61.58 \%)$ basal area was contributed by 36 species in study site I (Appendix 12).

3.3.4. Importance Value Index. The importance value index (IVI) of tree species showed a great variation, ranging from $1.1 \%$ to $9.8 \%$ in the overall study site (Appendix 2 ). The first top ten leading and ecologically most important tree species in the MFBR were C. zenkeri, P. altissima, B. unijugata, L. fraxinifolius, D. afromontana, A. toxicaria, B. abyssinica, C. toka, S. myriantha, and P. adolfi-friederici and contributed $68.5 \%$ of the IVI (Table 7 ). About $231.5 \%$ of the IVI was contributed by the remaining 75 species (Appendix 2).
More in detail, the results of IVI in the four study sites showed different values. The IVI value ranges from $3.6 \%$ to $18.3 \%$, and the highest IVI values exhibited tree species were C. zenkeri (18.3\%), D. abyssinica (13.4\%), A. toxicaria (13.2\%), and P. altissima (12.8\%), whereas the lowest tree species were $M$. butugi (4.3\%), A. grandibracteata (4.3\%), and $M$. lanceolata (3.6\%). About $123.5 \%$ of IVI values was contributed by the top ten tree species, whereas $176.5 \%$ was contributed by the remaining 27 tree species from the total of 300 IVI values in study site I (Table 7, Appendix 3).

In study site II, the IVI values of tree species range from 1.4 to $18.6 \%$; and about $129.4 \%$ of IVI was contributed by the top ten tree species, whereas 31 tree species contributed the remaining $170.5 \%$ IVI value. The highest IVI values exhibited tree species were $P$. altissima (18.6\%), C. zenkeri (16.3\%), L. fraxinifolius (16.3\%), and B. abyssinica (12\%), whereas the lowest values exhibited tree species were $P$. fulva (2.3\%), T. nobilis (1.8\%), and B. polystachya (1.4\%) (Table 7, Appendix 4).

The IVI value ranges from $1.29 \%$ to $14.1 \%$, and the highest IVI values exhibited tree species were $B$. unijugata (14.1\%), C. zenkeri (12.5\%), P. alnifolia (13.2\%), and $P$. altissima $(10.2 \%)$, whereas the lowest values exhibited tree species were $M$. butugi (4.3\%), A. grandibracteata (4.3\%), and M. lanceolata (3.6\%). From the total tree species, about $97.2 \%$ of IVI values was contributed by top ten tree species and $202.8 \%$ IVI was contributed by 37 species in study site III (Table 7, Appendix 5). In study site IV, the IVI values of tree species range from 3.5 to $16.3 \%$, and about $102.5 \%$ of IVI was contributed by the top ten tree species, whereas 35 tree species contributed the remaining $197.5 \%$ of IVI values.

3.4. Population Structure Woody Species. Tree species of the study area were divided into seven height and $\mathrm{DBH}$ classes. The overall height and $\mathrm{DBH}$ class distribution of all individuals of different sizes showed more or less an 
inverted J-shape distribution in the MFBR (Figures 7 (a) and $7(\mathrm{~b}))$. Similarly, the distribution of individuals in different height and DBH classes was showed more or less an inverted J-shape distribution in each study site (Figures 8(a) and 8(b)).

In this study, six representative patterns of population distribution based on $\mathrm{DBH}$ were revealed for tree species (Figures 9(a)-9(f)), which are mentioned as follows:

(1) Inverted J-shape, which shows a pattern where species frequency distribution has the highest frequency in the lower diameter classes and a gradual decrease towards the higher classes; e.g., Celtis zenkeri and Lecaniodiscus fraxinifolius in study site II; Blighia unijugata and Antiaris toxicaria in study site III; and Schefflera myriantha in study site IV.

(2) An increase from DBH class I to DBH class II and followed by a gradual decrease towards the higher DBH classes; e.g., Celtis zenkeri, Diospyros abyssinica, Antiaris toxicaria, Pouteria altissima, Lecaniodiscus fraxinifolius, and Celtis toka in study site I; Baphia abyssinica in study sites II and III; and Cyathea manniana, Dracaena afromontana, and Vernonia auriculifera in study site IV. This pattern represents more or less a normal population structure.

(3) U-shape, which shows a type of frequency distribution in which there is a high number of lowest and highest diameter classes but a very low number of intermediate classes; e.g., Pouteria altissima in study site II, and Ilex mitis and Schefflera abyssinica in study site IV.

(4) Irregular shape, which shows a pattern where the frequency is high at lower $\mathrm{DBH}$ classes but becomes irregular towards higher classes. The species that show such pattern are Pouteria altissima, Vernonia auriculifera, and Morus mesozygia in study site I; Antiaris toxicaria $\mathrm{n}$ study site II; and Pouteria alnifolia, Pouteria altissima, and Trichilia prieuriana in study site III.

(5) Bell-shaped is a type of frequency distribution in which several individuals in the middle diameter classes are high and lower in lower and higher diameter classes; e.g., Cordia Baphia abyssinica in site I; Cordia africana and Ficus exasperate in study site II; and Trilepisium madagascariense in study site IV.

(6) J-shaped; e.g., Allophylus abyssinicus in study site IV. This pattern represents abnormal population dynamics and shows poor reproduction and hampered regeneration since either most trees are not producing seeds due to age or there are losses due to predators after reproduction.

3.5. Regeneration Status of Woody Species. The total density of seedlings, saplings, and trees was $3461 \mathrm{ha}^{-1}, 1203 \mathrm{ha}^{-1}$, and $1350 \mathrm{ha}^{-1}$, respectively. Out of 80 trees species of $\mathrm{DBH}$
$>5 \mathrm{~cm}, 7$ tree species were not represented by seedlings and 11 tree species were not represented by saplings. Twelve tree species contributed $73.6 \%$ and $34.7 \%$ of the total seedling and sapling count, respectively (Table 10). They are $D$. abyssinica, A. toxicaria, P. altissima, B. unijugata, C. zenkeri, C. sylvaticus, L. fraxinifolius, B. abyssinica, G. mollis, P. alnifolia, D. afromontana, and G. saxifraga (Appendix 7). Regeneration status was represented by the following four distribution patterns (Figure 10):

Pattern (1): this pattern was exhibited by C. sativa, $L$. fraxinifolius, B. abyssinica, A. toxicaria, C. manniana, D. afromontana, and G. saxifrage (Figure 10(a), Tables 11-14)

Pattern (2): this pattern was exhibited by C. zenkeri, L. fraxinifolius, P. altissima, A. toxicaria, D. abyssinica, C. toka, B. unijugata, M. mesozygia, P. alnifolia, G. mollis, L. welwitschii, F. sur Forssk, B. abyssinica, M. oppositifolius, S. abyssinica T. tomentosa, S. myriantha, P. adolfi-friederici, and A. abyssinicus (Figure 10(b) and 10(c), Tables 11-14)

Pattern (3): this pattern was exhibited by F. mucuso, A. dimidiata, F. sur Forssk, G. buchananii, M. ferruginea, E. fischeri, F. exasperate, C. africana, L. senegalensis, A. grandibracteata, D. torrida, S. myriantha, C. oligocarpum, and E. ampliphylla (Figure 10(d), Appendixes 9-12)

Pattern (4): this pattern was exhibited by R. albersii, F. angolensis, C. africana, and A. chinense (Figure 10(e), Tables 11-14)

In addition, the regeneration status of the top ten species in each study site is indicated in Tables 11-14. The regeneration status of all the woody plant species was categorised as "not regenerate" (9.6\%), "poor" (30.7\%), "fair" (59.5\%), and "good" (10.8\%) in all sites.

In study site $\mathrm{I}$, the total density of the top ten species of trees, saplings, and seedlings were $313.5 \pm 3.8,176.8 \pm 3.5$, and 534.7 \pm 12.1 , respectively (Table 11, Appendix 8). Consequently, the regeneration status of saplings and seedlings showed the regeneration categories "not regenerate" (11.1\%), "poor" (17.1\%), "fair" (65.7\%), and "good" (2.9\%) in study site I (Figure 11). The densities of tree, sapling, and seedling were $339 \pm 3.1,225.6 \pm 7.5$, and $646.7 \pm 15.7$, respectively (Table 12 , Appendix 9), and the regeneration status showed different categories including "not regenerate" (7.1\%), "poor" (30.2\%), "fair" (51.2\%), and "good" (9.3\%) in the study site II (Figure 11).

Similarly, in study site III, the densities of trees, saplings, and seedlings were $270.1 \pm 3.1,320.9 \pm 7.5$, and $978 \pm 15.7$, respectively (Table 13, Appendix 10), and regeneration status was categorised as "not regenerate" (15.9\%), "poor" (13.6\%), "fair" (59.1\%), and "good" (9.1\%), (Figure 11). The densities of trees, saplings, and seedlings were $615 \pm 3.1$, $708.7 \pm 7.5$, and 1657.5 \pm 15.7 , respectively (Table 14, Appendix 11), and showed different regeneration statuses 


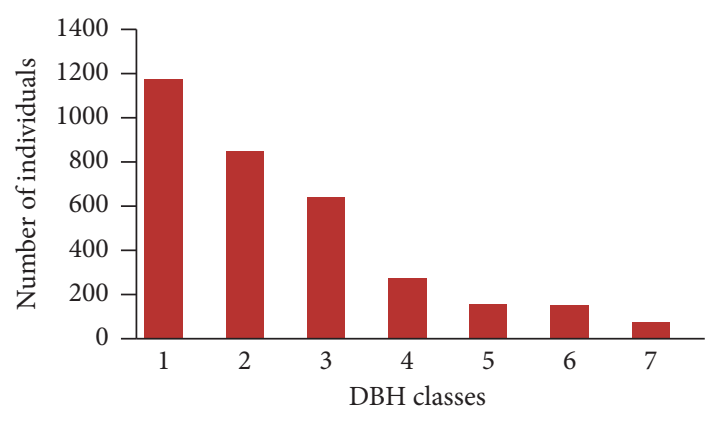

(a)

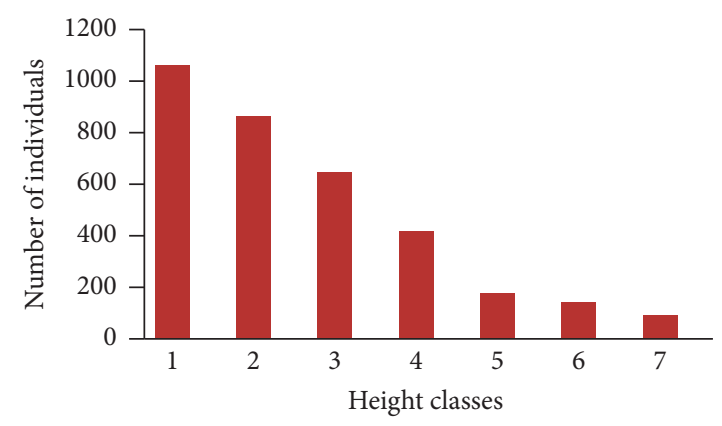

(b)

Figure 7: DBH and height class distribution of all individuals. (a) DBH classes: $1=5-10 \mathrm{~cm} ; 2=10.01-20 \mathrm{~cm} ; 3=20.01-30 \mathrm{~cm}$; $4=>30.01-40 \mathrm{~cm} ; 5=40.01-50 \mathrm{~cm} ; 6=50.01-80 \mathrm{~cm} ; 7=>80 \mathrm{~cm}$. (b) Height classes: $1=2-5 \mathrm{~m} ; 2=5.01-10 \mathrm{~m} ; 3=10.01-15 \mathrm{~m}$; $4=15.01-20 \mathrm{~m} ; 5=20.01-25 \mathrm{~m} ; 6=25.01-30 \mathrm{~m} ; 7=>30 \mathrm{~m}$.

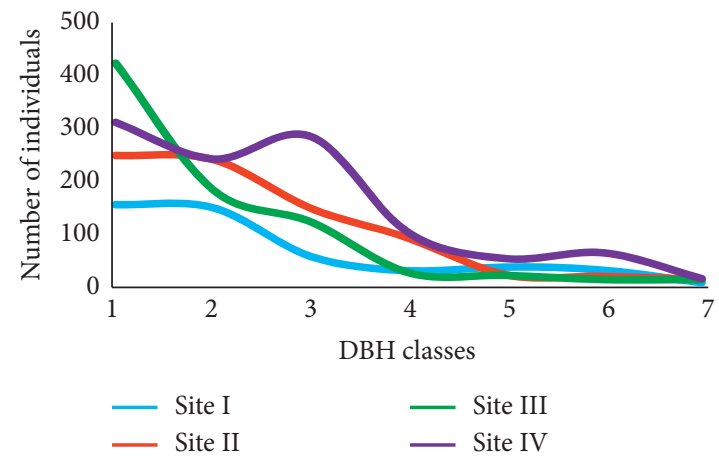

(a)

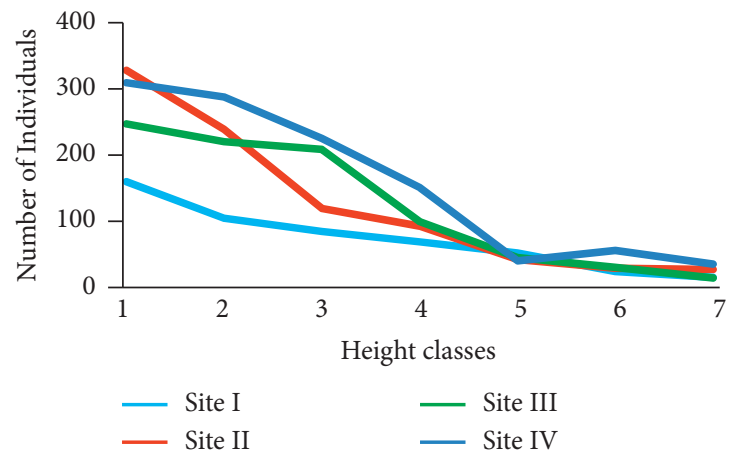

(b)

FIGURE 8: DBH and height class distribution of all individuals. (a) DBH classes: $1=5-10 \mathrm{~cm} ; 2=10.01-20 \mathrm{~cm}$; $3=20.01-30 \mathrm{~cm}$; $4=>30.0140 \mathrm{~cm} ; 5=40.01-50 \mathrm{~cm} ; 6=50.01-80 \mathrm{~cm} ; 7=>80 \mathrm{~cm}$. (b) Height classes: $1=2-5 \mathrm{~m} ; 2=5.01-10 \mathrm{~m} ; 3=10.01-15 \mathrm{~m} ; 4=15.01-20 \mathrm{~m}$; $5=20.01-25 \mathrm{~m} ; 6=25.01-30 \mathrm{~m} ; 7=>30 \mathrm{~m}$.

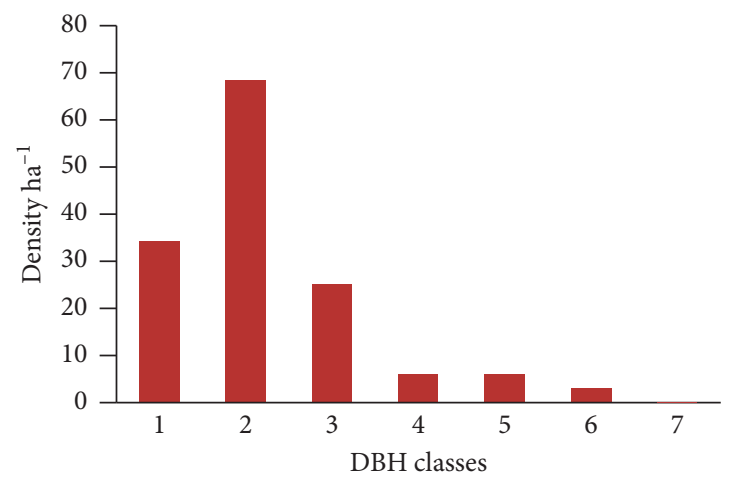

(a)

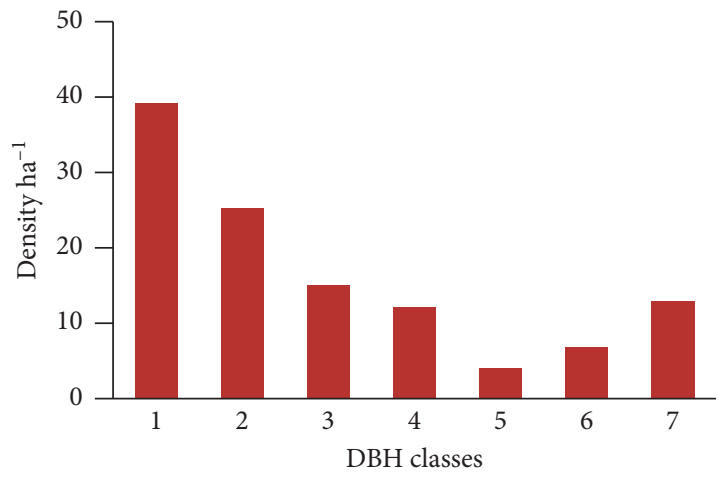

(b)

Figure 9: Continued. 


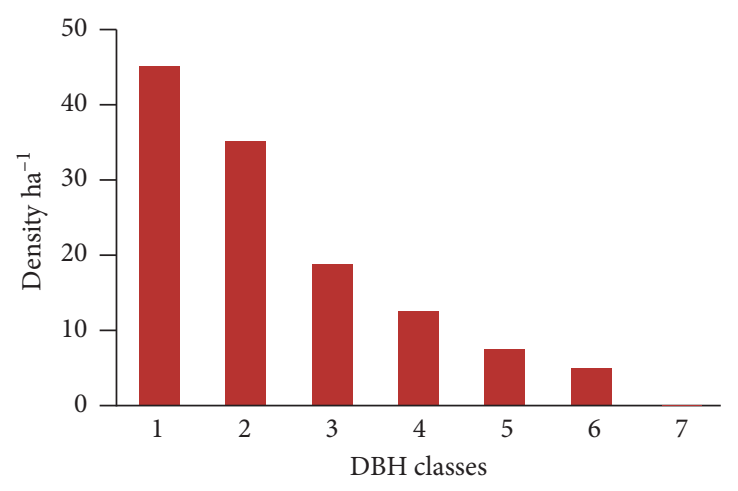

(c)

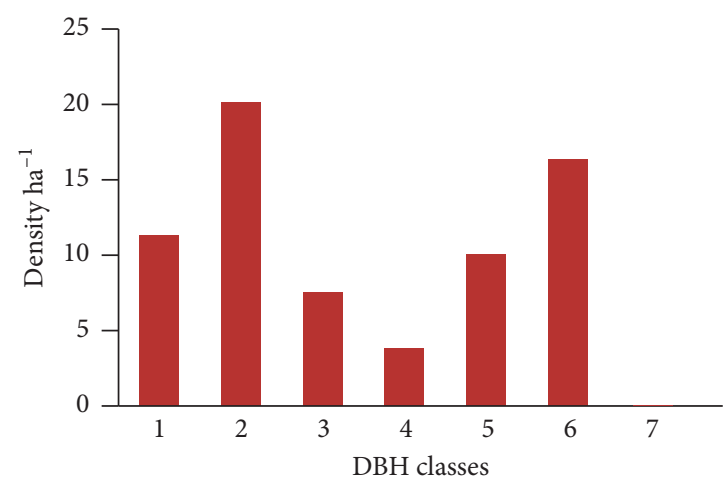

(e)

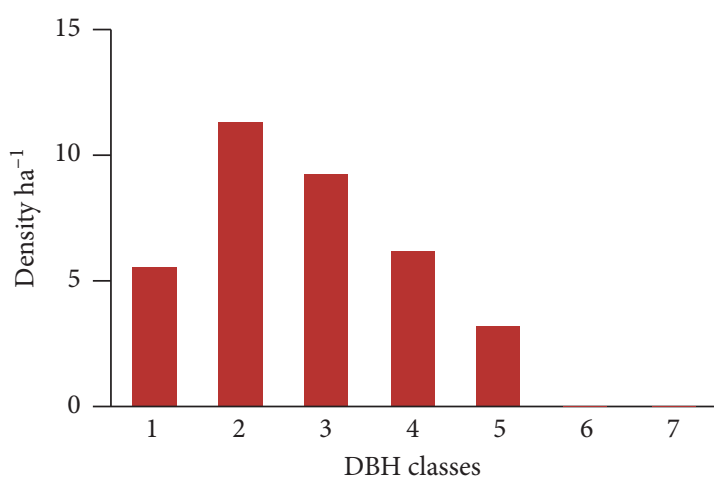

(d)

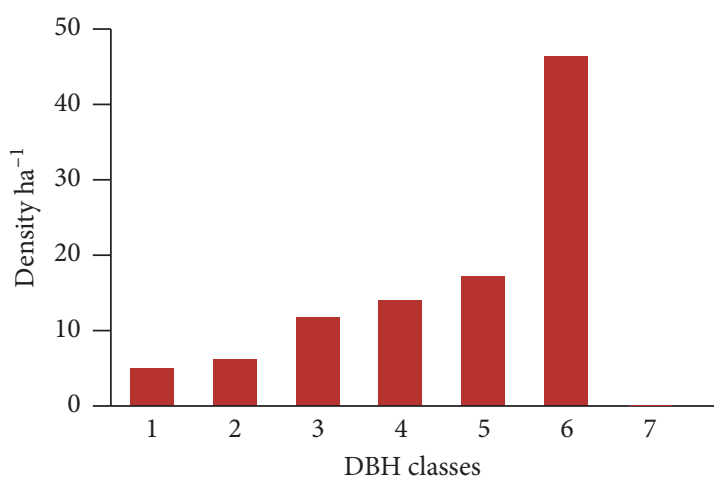

(f)

Figure 9: Pattern of frequency distribution of selected tree species over DBH classes $(1=5-10 \mathrm{~cm} ; 2=10.01-20 \mathrm{~cm} ; 3=20.01-30 \mathrm{~cm}$; $4=>30.01-40 \mathrm{~cm} ; 5=40.01-50 \mathrm{~cm} ; 6=50.01-80 \mathrm{~cm} ; 7=>80 \mathrm{~cm}$ ) in all sites. (a) C. zenkeri in site I. (b) P. altissima in site II. (c) B. unijugata in site III. (d) B. abyssinica in site I. (e) V. auriculifera in site I. (f) A. abyssinicus in site IV.

Table 10: List of top 12 species regeneration status in all sites.

\begin{tabular}{|c|c|c|c|c|}
\hline Species local name & SP & $\%$ & SD & $\%$ \\
\hline Diospyros abyssinica (Hiern) F. White & 43.8 & 3.6 & 606.6 & 17.5 \\
\hline Antiaris toxicaria Resch & 32.8 & 2.7 & 438.1 & 12.7 \\
\hline Pouteria altissima (A.Chev.) Baehni & 28.1 & 2.3 & 273.1 & 7.9 \\
\hline Blighia unijugata Bak. & 28.4 & 2.4 & 220.0 & 6.4 \\
\hline Celtis zenkeri A.Rich) Wedd & 31.3 & 2.6 & 189.7 & 5.5 \\
\hline Croton sylvaticus Krauss & 74.7 & 6.2 & 184.1 & 5.3 \\
\hline Lecaniodiscus fraxinifolius Bak. & 55.6 & 4.6 & 168.4 & 4.9 \\
\hline Baphia abyssinica Brummit & 50.9 & 4.2 & 149.1 & 4.3 \\
\hline Grewia mollis A.Juss. & 9.1 & 0.8 & 100.9 & 2.9 \\
\hline Pouteria alnifolia (Bak.) Roberty & 8.1 & 0.7 & 90.9 & 2.6 \\
\hline Dracaena afromontana Mildbr. & 32.8 & 2.7 & 79.7 & 2.3 \\
\hline Galiniera saxifraga (Hochst.) Bridson & 22.5 & 1.9 & 45.3 & 1.3 \\
\hline Total & 418.125 & 34.7 & 2545.938 & 73.6 \\
\hline
\end{tabular}

$\mathrm{SP}=$ sapling density; $\mathrm{SD}=$ seedling density.

including "not regenerate" (4.4\%), "poor" (11.1\%), "fair" $(62.2 \%)$, and "good" (22.2\%) in study site IV, (Figure 11).

3.6. Site Factors versus Regeneration Status. In the present analysis, site factors were computed and compared with the density of trees, saplings, and seedlings using Pearson correlation $(r)$. The correlation result between natural regeneration of trees, saplings, and seedlings and site factors revealed both positive and negative relationships (Table 15). Canopy openness and harvesting index showed a negative relationship with seedling, sapling, and tree density. The Pearson correlation coefficient between canopy openness with seedling, sapling, and tree density were negative $(r=-0.02, \quad P=0.09 ; \quad r=-0.26, \quad P=0.08 ; \quad$ and $r=-0.13$, $P=0.0004$, respectively). Similarly, the harvesting index 
TABLE 11: Regeneration status of top ten species in site I (Janje-Dope).

\begin{tabular}{|c|c|c|c|c|c|}
\hline Species name & Family name & TD & SP & SD & RS \\
\hline Celtis zenkeri A.Rich) Wedd & Urticaceae & 59.2 & 36.7 & 58.3 & $\mathrm{~F}$ \\
\hline Lecaniodiscus fraxinifolius Bak. & Sapindaceae & 39.6 & 27.9 & 56.7 & $\mathrm{~F}$ \\
\hline Pouteria altissima (A.Chev.) Baehni & Sapotaceae & 39.2 & 25.0 & 69.6 & $\mathrm{~F}$ \\
\hline Antiaris toxicaria Resch & Moraceae & 32.9 & 13.8 & 87.1 & $\mathrm{~F}$ \\
\hline Diospyros abyssinica (Hiern) F. White & Ebenaceae & 28.8 & 24.6 & 68.8 & $\mathrm{~F}$ \\
\hline Celtis toka (Forssk.) Hepper \& Wood & Ulmaceae & 26.3 & 7.9 & 22.1 & $\mathrm{~F}$ \\
\hline Blighia unijugata Bak. & Sapindaceae & 23.8 & 10.4 & 129.2 & $\mathrm{~F}$ \\
\hline Fagaropsis angolensis (Engl.) Dale & Rutaceae & 22.9 & 0.0 & 0.0 & NR \\
\hline Morus mesozygia Stapf. & Moraceae & 20.4 & 9.2 & 19.6 & $\mathrm{~F}$ \\
\hline Vernonia amygdalina Del. & Asteraceae & 20.4 & 21.3 & 23.3 & G \\
\hline Mean \pm std. error & & $313.5 \pm 3.8$ & $177 \pm 3.5$ & $534.7 \pm 12$ & \\
\hline
\end{tabular}

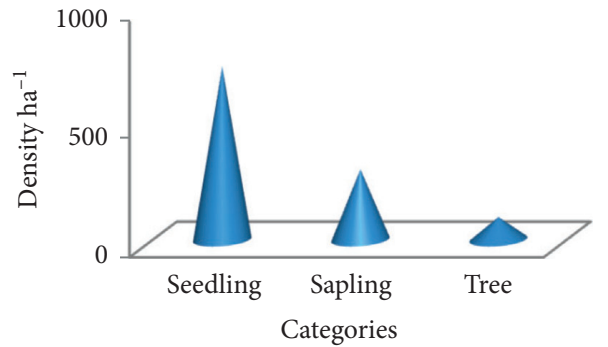

(a)

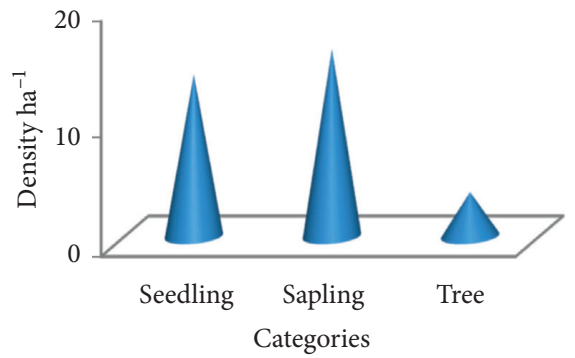

(c)

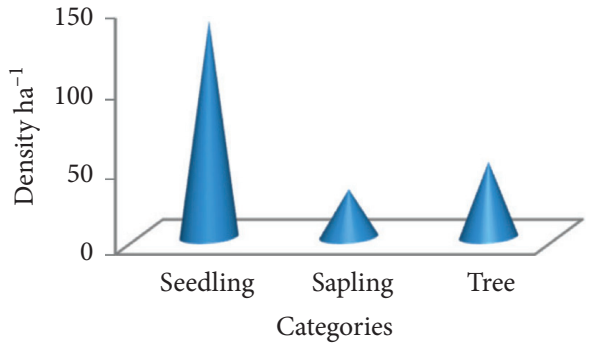

(b)

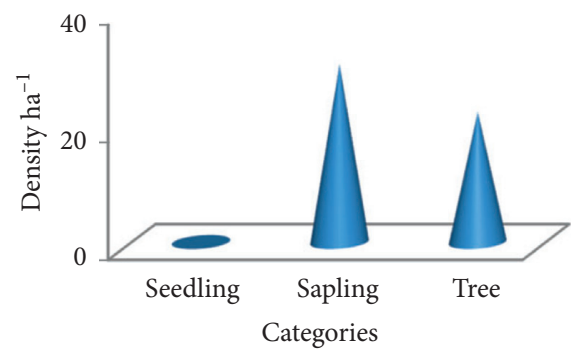

(d)

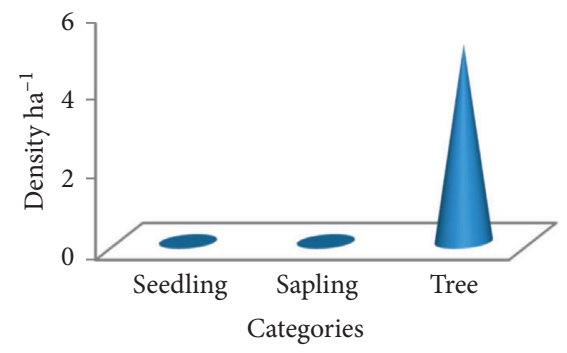

(e)

Figure 10: (a-e). Seedlings, saplings, and tree/shrub distribution of selected species occurring in each site of MFBR. (a) Cyathea manniana. (b) Pouteria altissima. (c) Vernonia hochstetteri. (d) Ficus mucuso. (e) Alangium chinense.

TABLE 12: Regeneration status of top ten species in site II (Newi-Baya).

\begin{tabular}{|c|c|c|c|c|c|}
\hline Species name & Family name & TD & SP & SD & RS \\
\hline Pouteria altissima (A.Chev.) Baehni & Sapotaceae & 47.9 & 30.4 & 137.9 & $\mathrm{~F}$ \\
\hline Celtis zenkeri A.Rich) Wedd & Urticaceae & 45.8 & 28.8 & 76.7 & $\mathrm{~F}$ \\
\hline Lecaniodiscus fraxinifolius Bak. & Sapindaceae & 45.0 & 66.7 & 123.3 & G \\
\hline Antiaris toxicaria Resch & Moraceae & 37.9 & 21.3 & 110.0 & $\mathrm{~F}$ \\
\hline Baphia abyssinica Brummit & Fabaceae & 37.5 & 58.8 & 94.6 & G \\
\hline Pouteria alnifolia (Bak.) Roberty & Sapotaceae & 27.1 & 4.6 & 27.9 & $\mathrm{~F}$ \\
\hline Grewia mollis A.Juss. & Tiliaceae & 26.3 & 4.6 & 38.3 & $\mathrm{~F}$ \\
\hline
\end{tabular}


TABle 12: Continued.

\begin{tabular}{llccc}
\hline Species name & Family name & TD & SP & SD \\
\hline Lannea welwitschii (Hiern) Engl. & Anacardiaceae & 24.6 & 5.8 & 16.3 \\
Ritchiea albersii Gilg & Capparidaceae & 23.5 & 0.0 & F \\
Ficus sur Forssk & Moraceae & 23.4 & 4.6 & NR \\
Mean \pm std. error & & $\mathbf{3 3 9} \pm \mathbf{3 . 1}$ & $\mathbf{2 2 5 . 6 \pm 7 . 5}$ & 21.7 \\
\hline
\end{tabular}

TABLE 13: Regeneration status of top ten species in site III (Gonchi-Gelesha).

\begin{tabular}{|c|c|c|c|c|c|}
\hline Species name & Family name & TD & SP & SD & RS \\
\hline Blighia unijugata Bak. & Sapindaceae & 41.3 & 25.8 & 150.4 & $\bar{F}$ \\
\hline Celtis zenkeri (A.Rich) Wedd & Urticaceae & 40.4 & 10.8 & 117.9 & $\mathrm{~F}$ \\
\hline Pouteria altissima (A.Chev.) Baehni & Sapotaceae & 33.8 & 7.1 & 156.7 & $\mathrm{~F}$ \\
\hline Baphia abyssinica Brummit & Fabaceae & 27.1 & 9.2 & 57.1 & $\mathrm{~F}$ \\
\hline Antiaris toxicaria Resch & Moraceae & 22.9 & 22.5 & 387.1 & G \\
\hline Pouteria alnifolia (Bak.) Roberty & Sapotaceae & 22.1 & 8.8 & 99.6 & $\mathrm{~F}$ \\
\hline Ficus ovate Vahl & Moraceae & 21.3 & 2.5 & 6.3 & $\mathrm{~F}$ \\
\hline Alangium chinense (Lour.) Harms & Alangiaceae & 20.8 & 0.0 & 0.0 & NR \\
\hline Mallotus oppositifolius (Geisel) Mull & Euphorbiaceae & 20.4 & 234.2 & 3.3 & $\mathrm{~F}$ \\
\hline Cordia africana Lam. & Boraginaceae & 20.0 & 0.0 & 0.0 & NR \\
\hline Mean \pm std. error & & $270 \pm 2.6$ & $321 \pm 22.6$ & $978 \pm 37.7$ & \\
\hline
\end{tabular}

TABLE 14: Regeneration status of top ten species in site IV (Kabo-Gumare).

\begin{tabular}{|c|c|c|c|c|c|}
\hline Species name & Family name & TD & SP & SD & RS \\
\hline Cyathea manniana Hook & Cyatheaceae & 96 & 298.75 & 736.25 & G \\
\hline Dracaena afromontana Mildbr. & Dracaenaceae & 90 & 131.25 & 318.75 & G \\
\hline Trilepisium madagascariense DC & Moraceae & 71 & 60 & 165 & $\mathrm{~F}$ \\
\hline Schefflera abyssinica (Hochst. ex A.Rich.) Harms & Araliaceae & 68 & 15 & 7.5 & $\mathrm{~F}$ \\
\hline Galiniera saxifraga (Hochst.) Bridson & Rubiaceae & 65 & 90 & 181.25 & G \\
\hline Triumfetta tomentosa Boj. & Tiliaceae & 45 & 41.25 & 82.5 & $\mathrm{~F}$ \\
\hline Schefflera myriantha (Bak.) Drake & Araliaceae & 45 & 0 & 32.5 & $\mathrm{~F}$ \\
\hline Pouteria adolfi-friederici (Engl.) Baehni & Sapotaceae & 45 & 45 & 38.75 & $\mathrm{~F}$ \\
\hline Allophylus abyssinicus (Hochst.) Radlk. & Sapindaceae & 45 & 10 & 60 & $\mathrm{~F}$ \\
\hline Macaranga capensis (Baill.) Sim & Euphorbiaceae & 45 & 17.5 & 35 & $\mathrm{~F}$ \\
\hline Mean \pm std. error & & $615 \pm 6$ & $708 \pm 28$ & $1657 \pm 70$ & \\
\hline
\end{tabular}

Note. $\mathrm{TD}=$ tree density, $\mathrm{SP}=$ sapling density, $\mathrm{SD}=$ seedling density, $\mathrm{RS}=$ regeneration status.

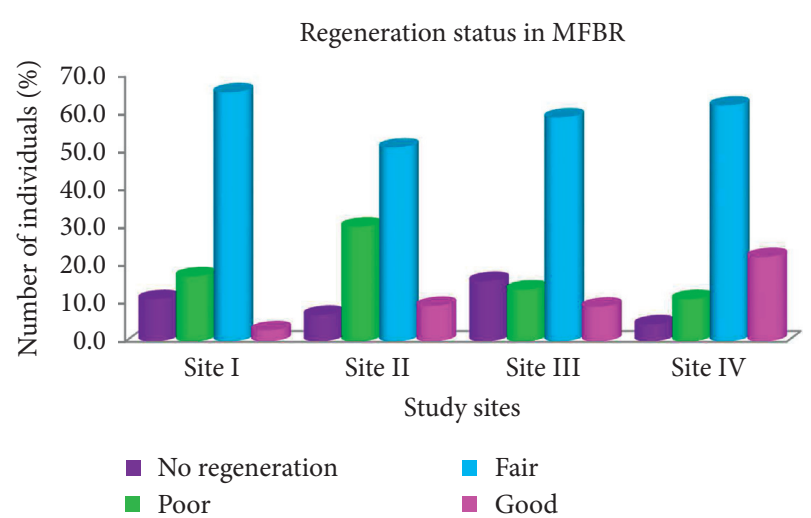

Figure 11: Regeneration status of woody species in MFBR.

showed a negative relationship with seedling, sapling, and tree density $(r=-0.03, P p=0.09 ; r=-0.29, P=0.1$; and $r=-0.03, P=0.000016$, respectively).

Elevation showed a significant positive relationship with sapling and tree density $(r=0.28, P=0.000001$, and $r=0.44$, $P=0.000001$, respectively), whereas tree density showed a significant negative relationship $(r=-0.02, P=0.000001)$. Slope also showed a positive relationship with seedling ( $r=0.03, P=0.07)$ and sapling $(r=0.12, P=0.09)$ density, whereas tree density showed a negative relationship $(r=-0.03, P=0.94)$. In addition, canopy openness and harvesting index $(r=-0.12, P=0.07$, and $r=-0.06, P=0.09$, respectively) showed a negative relationships with herbaceous cover. The abundance of the herbaceous cover showed a negative relationship $(r=-0.03, P=0.172)$ with the density of seedlings (Table 15).

\section{Discussion}

4.1. Species Composition. The number of species composition in Majang forest biosphere reserves (56 families, 115 genera, and 158 plant species) is higher than other forest sites including Agama forest (35 families, 65 genera, and 72 plant species) [41], Maji forest (55 families, 115 genera, and 146 plant species) [42], Wurg forest (40 families, 64 genera, and 76 plant species) [43], and Oda forest (32 families, 54 genera, and 62 plant species) [44] but lower than Gerba- 
TABLE 15: Pearson correlation matrix in the density of seedlings, saplings, and tree stems $\mathrm{ha}^{-1}$.

\begin{tabular}{lcccccccc}
\hline Variables & SD & SP & TD & HaCa & $\mathrm{CaOp}$ & $\mathrm{Hi}$ & $\mathrm{Slp}$ & $\mathrm{Elv}$ \\
\hline $\mathrm{SD}$ & & & & & & & & \\
$\mathrm{SP}$ & -0.11 & & & & & & & \\
$\mathrm{TD}$ & $-0.09^{*}$ & $0.26^{*}$ & & & & & & \\
$\mathrm{HaCa}$ & -0.03 & 0.12 & $0.08^{*}$ & & & & & \\
$\mathrm{CaOp}$ & -0.02 & -0.26 & $-0.13^{*}$ & -0.12 & & & & \\
$\mathrm{Hi}$ & -0.03 & -0.29 & $-0.03^{*}$ & -0.06 & 0.11 & & & \\
$\mathrm{Slp}$ & 0.03 & 0.12 & $0.03^{*}$ & -0.01 & -0.13 & -0.18 & & \\
$\mathrm{Elv}$ & $-0.02^{*}$ & $0.28^{*}$ & $0.44^{*}$ & $0.05^{*}$ & $0.15^{*}$ & $0.05^{*}$ & $0.12^{*}$ & \\
\hline
\end{tabular}

*Significant at $P<0.05, \mathrm{SD}=$ seedling density, $\mathrm{SD}=$ sapling density, $\mathrm{TD}=$ tree density, $\mathrm{HaCa}=$ herbaceous cover, $\mathrm{CaOp}=$ canopy openness, $\mathrm{Hi}=$ harvesting index, $\mathrm{Slp}=$ slope, and Elv $=$ elevation

Dima forest (69 families, 145 genera, and 180 plant species) [45], Yayu forest (72 family, 163 genera, and 217 plant species) [4], and Bonga forest ( 92 families, 207 genera, and 285 plant species) [42]. The variation of plant species over different habitats of the forest could be attributed to a number of environmental factors, which impose impacts in both temporal and spatial scales [46]. Thus, environmental heterogeneity, regeneration capacity, moderate disturbance, and competition might shape and determine species richness of the forest. Moreover, from the identified woody species, Majang forest biosphere reserves sheltered relatively few numbers of endemic plant species to Ethiopia [47], i.e., Bothriocline schimperi, Clematis longicauda, and Vepris dainellii.

\subsection{Vegetation Structure}

4.2.1. Density of Woody Species. The stem densities varied with species composition, diameter size classes, and the degree of disturbance. Specifically, the stem densities of tree species with $\mathrm{DBH}>5 \mathrm{~cm}$ in four study sites ranged from 1232 to 1478 stems $\mathrm{ha}^{-1}$ (Table 5) are lower than those reported from Wurg forest $\left(1745 \mathrm{ha}^{-1}\right)$ [43], Masha forest $\left(1681 \mathrm{ha}^{-1}\right)$ [48], and Gelesha forest $\left(1659 \mathrm{ha}^{-1}\right)$ [49] in southwestern moist Afromontane forest and higher than a moist tropical forest $\left(843 \mathrm{stems} \mathrm{ha}^{-1}\right)$ [50]. On the other hand, the density mentioned in this study is more or less comparable with that of Agama forest $\left(1446 \mathrm{ha}^{-1}\right)$ [41]. The variation of tree densities of MFBR study sites may be due to variations in elevation, aspect, species composition, age, structure [51], and disturbance levels [52].

The ratio of tree/shrub density $(10 \mathrm{~cm}<\mathrm{DBH}<20 \mathrm{~cm}$ and $>20 \mathrm{~cm}$ ) was taken as a measure of the class size distribution [56]. Accordingly, the value of the tree/shrub density ratio was 1.4 in Majang forest biosphere reserves, which is more or less comparable with Gelesha [53] and Gurafreda [58]. This similarity may be due to connection with geographical location, climatic condition, and altitude factors. On the other hand, the ratio $\mathrm{a} / \mathrm{b}$ at MFBR was lower than that at Wurg, Agama, Jima, Menna Angetu, Belete, Masha, Masha Anderacha, and Komto; it indicates that all studies have higher proportions of small-sized individuals than the MFBR. This difference may be due to in the stage of secondary succession of the forests (Table 16).
TABle 16: Comparisons of tree densities with $\mathrm{DBH} 10-20 \mathrm{~cm}$ (a) and $\mathrm{DBH}>20 \mathrm{~cm}$ (b) of MFBR with eleven other moist Afromontane forests in southwestern Ethiopia.

\begin{tabular}{lcccccc}
\hline \multirow{2}{*}{ Name of forests } & \multicolumn{3}{c}{ Density ha $^{-1}$} & Ratio & Source \\
& (a) & $\%$ & (b) & $\%$ & a/b & \\
\hline Wurg & 516 & 76.3 & 160.5 & 23.7 & 2.3 & {$[43]$} \\
Agama & 556.3 & 66.4 & 280.9 & 33.6 & 2.0 & {$[41]$} \\
Gelesha & 215 & 56.9 & 163 & 43.1 & 1.3 & {$[49]$} \\
Gelesha & 315.4 & 56.3 & 244.6 & 43.7 & 1.3 & {$[53]$} \\
Belete & 305.1 & 67.2 & 149 & 32.8 & 2.0 & {$[54]$} \\
Masha & 633 & 68.9 & 286 & 31.1 & 2.2 & {$[48]$} \\
Komto & 330 & 60.6 & 215 & 39.4 & 1.5 & {$[55]$} \\
Menna Angetu & 292 & 67.7 & 139 & 32.3 & 2.1 & {$[56]$} \\
Harenna & 335 & 64.5 & 184 & 35.5 & 1.8 & {$[57]$} \\
Guraferda & 633 & 55.9 & 499 & 44.1 & 1.3 & {$[58]$} \\
Masha & 387.7 & 70.7 & 160.5 & 29.3 & 2.4 & {$[59]$} \\
Anderacha & & & & & & Present \\
Majang & 617.5 & 57.8 & 450.3 & 42.2 & 1.4 & study \\
\hline
\end{tabular}

4.2.2. Frequency of Woody Species. Frequency indicates the homogeneity or heterogeneity of a given stand $[27,60]$, an occurrence of a species in a given area which indicates how species are distributed [27, 61]. In all study sites of MFBR, the frequency value of woody species ranges from $0.1 \%$ to 99\%. The highest frequency was shown by Celtis zenkeri $(88 \%)$ in study site I, Pouteria altissima (100\%) in study site II, Celtis zenkeri (95\%) in study site III, and Dracaena afromontana and Cyathea manniana (100\%) in study site IV (Table 7). These may be due to a wide range of seed dispersal mechanisms like wind, livestock, wild animals, and birds.

High values in lower frequency classes and low values in higher frequency classes indicate a high degree of floristic heterogeneity [62]. The frequency distribution of woody species in the MFBR shows that the number of tree species found in the first frequency classes is higher (A and B) and gradually decreases towards higher frequency classes ( $D$ and E), which is similar to that mentioned by Dibaba et al. [41] in Agama forest, Girma and Melese [43] in Wurg forest, Edae and Soromessa [49] in Gelesha forest in southwestern moist Afromontane, and Dibaba et al. [63] in dry Afromontane forest. In contrast, Mekonen et al. [64] found that the number of tree species found in the first frequency classes is lower (A and B) and gradually increases towards higher frequency classes (D and E) in Woynwuha natural forest in northwestern Ethiopia. Such variation may be due to uniform species composition or homogeneity in the area.

4.2.3. Basal Area. A species with a greater basal area could be considered the most important species in a given study forest [65]. Basal area per hectare used as an indicator of degradation level or status of standing stock. If the basal area is very small, we can conclude that the forest is degrading. The total basal area of all woody species in the MFBR was about $139.8 \mathrm{~m}^{2}$ with $\mathrm{DBH}>5 \mathrm{~cm}$, which is greater than that of Wurg, Belete, Gelesha, Bibita, and Agama in moist 
Afromontane forests, southwestern Ethiopia, and Dodola, Wof-Washa, Manna Angetu, and Yemrehane Kirstos in dry Afromontane forests while lower than that of Wof-Washa in dry Afromontane forest and Masha Anderacha in moist Afromontane, southwestern Ethiopia, which is adjacent to the current study (Table 17).

There was a significant difference between the MFBR study sites in terms of basal area. The total basal area ranges ( 56.8 to $76.3 \mathrm{~m}^{2} \mathrm{ha}^{-1}$ ) in the four study sites (I-IV) (Table 5) are greater than the range of basal area $\left(17\right.$ to $\left.40 \mathrm{~m}^{2} \mathrm{ha}^{-1}\right)$ reported in dry forests of the world [70]. The increments in the basal area from sites I-IV may be due to more number of individuals in higher diameter size classes with increments in elevation and minimal incidences of disturbance within the study site.

The highest basal area of individual tree species in the study site was contributed by C. zenkeri in the study sites I and III, $P$. altissima in study site II, and D. afromontana in site IV, whereas the highest density was exhibited by D. abyssinica in study site I, L. fraxinifolius in study site II, B. unijugata in study site III, and C. manniana in site IV. This shows that the species with the highest basal area do not necessarily have the greater density and vice versa, which is also true, indicating a size difference between species [65].

4.2.4. Importance Value Index. The importance value index is used for comparison of ecological key species [62] and ranking species for management and conservation priority. In this respect, the IVI of woody species of the MFBR was calculated from relative density, relative dominance, and relative frequency [71]. The species with larger IVI need monitoring and management, whereas the species with smaller importance value index need high conservation effort [62]. In this study, the maximum IVI was contributed by $C$. zenkeri (9.8) and the lowest was by F. thonningii in the MFBR or overall study area (1.1). The most ecologically significant tree species in the MFBR were $C$. zenkeri, P. altissima, B. unijugata, L. fraxinifolius, D. afromontana, A. toxicaria, B. abyssinica, C. toka, S. myriantha, and $P$. adolfi-friederici and could influence the overall forest structure (Table 7 and Appendix 2).

More in detail, the highest IVI value was exhibited by C. zenkeri in study site I, P. altissima in study site II, B. unijugata in study site III, and C. manniana study site IV, whereas the least IVI value was exhibited by M. lanceolata in study site I, B. polystachya in study site II, L. zeylanica in study site III, and F. sur in study site IV (Table 7, Appendixes 3-6). According to the criteria set by the Institute of Biodiversity Conservation and Research [38], the total values of IVI in each species in all study sites were under conservation/restoration priority classes $1-3$ (priority class $1=<1$, priority class $2=1-10$, and priority classes $3=10.1-20$ ). Therefore, the woody species those showed the lower IVI may indicate threatened species and need immediate conservation measure.

4.2.5. Population Structure of Woody Species. Population structure refers to the spreading of individual species in random diameter-height size classes to provide the overall
TABLE 17: Comparison basal area per hectare of Majang biosphere reserves natural forest with other ten moist Afromontane forests in Ethiopia.

\begin{tabular}{lcc}
\hline Name of forests & Basal area $\left(\mathrm{m}^{2} \mathrm{ha}^{-1}\right)$ & Sources \\
\hline Wof-Washa & 153.26 & {$[66]$} \\
Masha & 142.61 & {$[48]$} \\
Majang & $\mathbf{1 3 9 . 8}$ & Present study \\
Dodola & 129 & {$[67]$} \\
Wurg & 126.5 & {$[43]$} \\
Belete & 103.5 & {$[54]$} \\
Gelesha & 98.87 & {$[53]$} \\
Menna Angetu & 94.2 & {$[56]$} \\
Agama & 80.8 & {$[41]$} \\
Yemrehane Kirstos & 72 & {$[68]$} \\
Bibita & 69.9 & {$[69]$} \\
\hline
\end{tabular}

regeneration profile of woody and shrub species $[72,73]$. The structural patterns of the population could be understood as an indication of variation in population dynamics that may occur because of natural characters or due to humans and livestock interventions [74, 75]. In this study, the population patterns of height and DBH class distribution of all individuals in different sizes showed more or less an inverted J-shape distribution in the total results of MFBR (Figures 7(a) and 7(b)). This means species frequency distribution had the highest frequency in the lower diameter and height classes and a gradual decrease towards the higher classes. The possible reason for the decreasing higher diameter class may be due to illegal logging of middle and high diameter class trees for various purposes by local people such as for fencing, farm implementing, house construction, and fuel wood. Similarly, the distribution of individuals in different height and DBH classes' dominant species showed more or less an inverted J-shape distribution in each study site (Figures 8(a) and 8(b)). An inverted J-shape population pattern is a normal plant population structure and shows the occurrence of species in a healthier condition. This is similar to other findings that reported moist Afromontane forest in southwestern parts of Ethiopia $[41,43,48,53-55,57,58,69,76]$ and dry Afromontane forest [66-68]. However, the overall population pattern does not indicate the trends of population dynamics and recruitment processes of individual species [20,63]. Specifically, six representative patterns of population distribution were exhibited in the MFBR, which is similar to other findings in Ethiopia [20, 43, 57, 77, 78]. Hence, generally assessing the population structure is important to provide a preliminary indication about the regeneration status of woody plants and shrubs in a studied forest $[78,79]$.

4.2.6. Regeneration Status of Woody Species. The status of forest regeneration depends on the composition, distribution, and density of seedlings, saplings, and adult trees in the forest [12]. The recruitment or regeneration condition of woody species is one of the main factors that are valuable to evaluate forest conservation status [80]. The population 
structure, characterised by the presence of a sufficient population of seedlings, saplings, and adults, indicates the successful regeneration of forest species [81]. In this study, the regeneration status of saplings and seedlings showed four regeneration patterns (no regeneration, poor, fair, and good). The "poor" and "no regeneration" patterns were exhibited by $28.1 \%, 44.3 \%, 29.2 \%$, and $15.5 \%$ of the woody plants in study sites I, II, III, and IV, respectively, of MFBR. Thus, the variation of hamper regeneration among study sites may be due to the presence of anthropogenic factors and environmental factors [12,82]. This result is more or less similar to that reported in Berbere forest (32.26\%) [83], Wof-Washa (48\%) [84], Central Highland (20.9\%) [85], and Wurg forests (14\%) [43]. The lower seedling count in the MFBR showed limited regeneration potential that could be due to unlimited vegetation exploitation by the local community. However, there are some germination of seeds due to few remaining mother trees; most of these seedlings vanished before reaching sapling and mature stages for various reasons including grazers, browsers pressure, and illegal exploitation [86].

The "poor" and "no regeneration" of the woody species in the study sites of MFBR generally falls below half percent. These conditions might have occurred through the existence of disturbances such as overgrazing [9, 66, 87-89], fuel wood collection, agricultural expansion, settlement, and poor biotic potential of tree species that affects the fruit setting and germination of seeds $[20,90,91]$. Poor regeneration is an indication of poor reproduction and hampered regeneration, which is due to old age individuals and loss of seeds by predators after reproduction or successful conversion of seedling to sapling stage [92]. Moreover, individuals in young stages of any species are more vulnerable to any kind of environmental stress and anthropogenic disturbance [93]. Therefore, the absence of seedlings and saplings of woody species designates the immediate requirement of a forest management plan to improve forest regeneration $[20,94]$.

4.3. Site Factors versus Regeneration Status. In this study area, the correlation result between natural regeneration of trees, saplings, and seedlings and site factors revealed both positive and negative relationships (Table 15). The correlation analysis of elevation indicated a negative relationship with seedling and a positive relationship with sapling densities. The negative relationship of elevation with seedling density may be due to human disturbance coupled with population density increment when elevation increased, which is similar to the findings of other tropical forests [95]. The slope also showed a positive relationship with seedling and sapling densities. This may be due to difficulty to reach an area of human disturbance with increasing of the slope (Table 15).

Harvesting index and canopy openness showed a negative relationship with seedling, sapling, and tree densities, which ultimately affects the regeneration status of the species. For instance, illegal logging of tree species leads to a reduction in the mother tree or seed sources, and it facilitates the growth of understory, shrubs, and composition of species in the area. This also enforces abiotic stress like evapotranspiration and loss of soil moisture that retard regeneration [88]. It was also reported that the canopy openness of forests affects the species composition, richness, and regeneration of tree species [96]. However, different studies reported that most species had increased regeneration with increased canopy openness $[97,98]$. This might be due to the species characteristics of shade-tolerant and intolerant species that exhibit variations of regeneration with the degree of canopy openness.

Numerous structural characteristics influence the regeneration of species, especially the stem density of trees and abundance of herbaceous cover. The density of trees had a negative relationship with that of seedlings; this may be due to high competition with trees and herbaceous cover, causing the survival of seedlings. This result coincides with previous results in tropical forests [99]. In other studies, however, positive correlations were found between densities of trees and herbaceous cover and seedling density [100]. The interactions between seedlings and herbaceous cover result in forest dynamics because dense herbaceous cover decreases light availability near the forest floor and results in the decline of seedling regeneration [101]. The seedlings density was reduced in response to high herbaceous cover, indicating competitive effects for space and resources between seedlings and their nontree competitors. Higher herbaceous cover played a major role in preventing successful seed germination, seedling establishment, growth, and survival [102].

\section{Conclusion and Recommendation}

The current study delivers important information about the state of woody plant species composition, structures, and regeneration of woody plant species and the impacts of site factors on the natural regeneration of tree species of Majang forest biosphere reserves. The results revealed that the diversity is high, with a total of 158 plant species belonging to 115 genera and 56 families. Among these, the plant species Dracaena afromontana, Celtis zenkeri, and Pouteria altissima were the most frequent and dominant with greater important value index (IVI) in MFBR. The overall height and DBH class distribution of all individuals of different sizes showed more or less an inverted J-shape distribution in MFBR. However, a few numbers of species showed an unhealthy population structure or poorly represented either in the lower or higher DBH and height classes. Considering seedling, sapling, and tree densities, the regenerating status of all the woody plant species were categorised as "not regenerate" (9.6\%), "poor" (30.7\%), "fair" (59.5\%), and "good" $(10.8 \%)$ in all sites. The correlation result between natural regeneration of trees, saplings, and seedlings and site factors revealed both positive and negative relationships. However, the main threat to the biosphere reserve is the illegal logging of some tree species for different purposes. Therefore, awareness creation on sustainable forest management, utilisation, conservation of priority species, and livelihood 
diversification to the local community and encouraging community and private woodlot plantation in the transitional zone of the biosphere reserves are recommended.

\section{Data Availability}

The data used to support the findings of this study are available from the corresponding author upon request.

\section{Conflicts of Interest}

The authors declare that there are no conflicts of interest.

\section{Acknowledgments}

The authors thank the Center of Environmental Sciences, Addis Ababa University, for their contribution. This study was funded by Addis Ababa University.

\section{Supplementary Materials}

Appendix 1: list of species in MFBR. Appendix 2: stand structure and IVI of species in all the sites of the MFBR. Appendix 3: stand structure and IVI of species in site I of the MFBR. Appendix 4: stand structure and IVI of species in site II of the MFBR. Appendix 5: stand structure and IVI of species in site III of the MFBR. Appendix 6: stand structure and IVI of species in site IV of the MFBR. Appendix 7: seedlings, saplings, and trees per hectare of woody species in MFBR. Appendix 8: seedlings, saplings, and trees per hectare of woody species with regeneration status in study site I. Appendix 9: seedlings, saplings, and trees per hectare of woody species with regeneration status in study site II. Appendix 10: seedlings, saplings, and trees per hectare of woody species with regeneration status in study site III. Appendix 11: seedlings, saplings, and trees per hectare of woody species with regeneration status in study site IV. Appendix 12: Dominant trees with their percentage basal area of MFBR. Appendix 13: basal area per ha in site I of the MFBR. Appendix 14: basal area per ha in site II of the MFBR. Appendix 15: basal area per ha in site III of the MFBR. Appendix 16: basal area per ha in site IV of the MFBR. (Supplementary Materials)

\section{References}

[1] E. Kelbessa, "Threatened endemic plants of Ethiopia," Plants Used in African Traditional Medicine as Practiced in Ethiopia and Uganda, pp. 35-55, Addis Ababa University, Addis Ababa, Ethiopia, 1992.

[2] Z. Woldu, "The population, health and environment nexus, the need for integration and networking," A Background Paper for the Establishment and Launching of PHE, p. 34, Addis Ababa University, Addis Ababa, Ethiopia, 2008.

[3] E. Kelbessa and S. Demissew, "Diversity of vascular plant taxa of the flora of Ethiopia and Eritrea," Ethiopian Journal of Biological Sciences, vol. 13, pp. 37-45, 2014.

[4] T. W. Gole, Vegetation of the Yayu Forest in SW Ethiopia: Impacts of Human use and Implicatiions for in Situ Conservation of Wild Coffea Arabica L. Populations, Vol. 10, Cuvillier Verlag, Göttingen, Germany, 2003.
[5] F. S. Wakjira, Biodiversity and Ecology of Afromontane Rainforests with Wild Coffea Arabica L. Populations in Ethiopia, Cuvillier Verlag, Göttingen, Germany, 2006.

[6] D. Tewabe, "Spatial and temporal distributions and some biological aspects of commercially important fish species of Lake Tana, Ethiopia," Journal of Coastal Life Medicine, vol. 2, no. 8, pp. 589-595, 2014.

[7] B. A. Wondimagegnhua, "Fighting hidden hunger: diversity, composition and nutrient adequacy of diets of lactating mothers in Jimma Zone, Southwest Ethiopia," in Proceedings of the Conference on International Research on Food Security, Vienna, Austria, September 2016.

[8] G. Tesfaye, D. Teketay, M. Fetene, and E. Beck, "Regeneration of seven indigenous tree species in a dry Afromontane forest, southern Ethiopia," Flora-Morphology, Distribution, Functional Ecology of Plants, vol. 205, no. 2, pp. 135-143, 2010.

[9] G. Tesfaye, D. Teketay, and M. Fetene, "Regeneration of fourteen tree species in Harenna forest, southeastern Ethiopia," Flora-Morphology, Distribution, Functional Ecology of Plants, vol. 197, no. 6, pp. 461-474, 2002.

[10] S. Shibru and G. Balcha, "Composition, Structure and regeneration status of woody species in Dindin Natural Forest, Southeast Ethiopia: an implication for conservation," Ethiopian Journal of Biological Sciences, vol. 3, no. 1, pp. 15-35, 2004.

[11] L. H. O. Wadt, K. A. Kainer, C. L. Staudhammer, and R. O. P. Serrano, "Sustainable forest use in Brazilian extractive reserves: natural regeneration of Brazil nut in exploited populations," Biological Conservation, vol. 141, no. 1, pp. 332-346, 2008.

[12] Z. A. Malik and A. Bhatt, "Regeneration status of tree species and survival of their seedlings in Kedarnath Wildlife Sanctuary and its adjoining areas in Western Himalaya, India," Tropical Ecology, vol. 57, no. 4, pp. 677-690, 2016.

[13] F. Ahmadi, A. R. Sadeghi, and A. R. Eskandarinezhad, "Ecological quality improvement of urban landscapes with emphasis on sustainable development principles case study: river of Darabad Valley, Tehran, Iran," European Journal of Sustainable Development, vol. 5, no. 3, p. 91, 2016.

[14] R. Duchok, K. Kent, A. Devi, and A. Khumbongmayum, "Population structure and regeneration status of medicinal tree Illicium griffithii in relation to disturbance gradients in temperate broad-leaved forest of Arunachal Pradesh," Current Science, vol. 89, pp. 673-676, 2005.

[15] D. Teketay, K. Kashe, J. Madome et al., "Enhancement of diversity, stand structure and regeneration of woody species through area exclosure: the case of a mopane woodland in northern Botswana," Ecological Processes, vol. 7, no. 1, p. 5, 2018.

[16] P. Pokhriyal, "Regeneration status of tree species in forest of Phakot and Pathri Rao watersheds in Garhwal Himalaya," Current Science, vol. 98, pp. 171-175, 2010.

[17] R. Tripathi and M. Khan, "Regeneration dynamics of natural forests," Proceedings-Indian National Science Academy, vol. 73, no. 3, p. 167, 2007.

[18] K. Aliyi, K. Hundera, and G. Dalle, "Floristic composition, vegetation structure and regeneration status of kimphe lafa natural forest, Oromia regional state, West Arsi, Ethiopia," Research \& Reviews: Journal of Life Sciences, vol. 5, no. 1, pp. 19-32, 2015.

[19] S. Tadese, T. Soromessa, and T. Bekele, "Analysis of the current and future prediction of land use/land cover Change using remote sensing and the CA-markov model in majang forest biosphere reserves of Gambella, southwestern 
Ethiopia," The Scientific World Journal, vol. 2021, Article ID 6685045, 18 pages, 2021.

[20] G. Gebeyehu, T. Soromessa, T. Bekele, and D. Teketay, "Species composition, stand structure, and regeneration status of tree species in dry Afromontane forests of Awi Zone, northwestern Ethiopia," Ecosystem Health and Sustainability, vol. 5, no. 1, pp. 199-215, 2019.

[21] M. Batisse, "Biosphere reserves: a challenge for biodiversity conservation \& regional development," Environment: Science and Policy for Sustainable Development, vol. 39, no. 5, pp. 6-33, 1997.

[22] M. Özyavuz, "Biosphere reserves," in The BiosphereIntechOpen, London, UK, 2012.

[23] Z. Bergman, M. Bergman, K. Fernandes, D. Grossrieder, and L. Schneider, "The contribution of UNESCO chairs toward achieving the UN sustainable development goals," Sustainability, vol. 10, no. 12, p. 4471, 2018.

[24] C. M. Peters and W. Bank, The Ecology and Management of Non-timber Forest Resources, The World Bank, Washington, DC, USA, 1996.

[25] F. Ib, D. Sebsebe, and P. v. Breugel, Atlas of the Potential Vegetation of Ethiopia, The Royal Danish Academy of Sciences and Letters, Copenhagen, Denmark, 2010.

[26] W. B. Inventory, Strategic Planning Project (WBISPP), Forest Resources of Ethiopia, Addis Ababa, Ethiopia, 2004.

[27] M. Kent, Vegetation Description and Data Analysis: A Practical Approach, John Wiley \& Sons, Hoboken, NJ, USA, 2011.

[28] G. Stride, C. D. Thomas, S. Benedick et al., "Contrasting patterns of local richness of seedlings, saplings, and trees may have implications for regeneration in rainforest remnants," Biotropica, vol. 50, no. 6, pp. 889-897, 2018.

[29] E. Van der Maarel and J. Franklin, Vegetation Ecology, John Wiley \& Sons, Hoboken, NJ, USA, 2012.

[30] R. Sagar, A. Raghubanshi, and J. Singh, "Tree species composition, dispersion and diversity along a disturbance gradient in a dry tropical forest region of India," Forest Ecology and Management, vol. 186, no. 1-3, pp. 61-71, 2003.

[31] I. Hedberg, O. Hedberg, and S. Edwards, Flora of Ethiopia and Eritrea: Pittosporaceae to Araliaceae, Vol. 3, Addis Ababa University, Addis Ababa, Ethiopia, 1989.

[32] I. Hedberg, S. Edwards, and S. Phillips, Flora of Ethiopia and Eritrea: Poaceae (Gramineae), Vol. 7, Addis Ababa University, Addis Ababa, Ethiopia, 1995.

[33] R. Shukla and P. Chandel, Plant Ecology and Soil Science, S. Chand \& Company Limited, New Delhi, India, 9th edition, 2000.

[34] F. Dallmeier, Long-term Monitoring of Biological Diversity in Tropical Forest Areas: Methods for Establishment and Inventory of Permanent Plot, pp. 11-46, UNESCO, Paris, France, 1992.

[35] R. Misra, Ecology Work Book'(N. Delhi), Oxford and IBH Publication House, New Delhi, India, 1968.

[36] B. Husch, T. W. Beers, and J. A. Kershaw Jr., Forest Mensuration, John Wiley \& Sons, Hoboken, NJ, USA, 2002.

[37] A. Magurran, Measuring Biological Diversity, pp. 106-108, John Wiley \& Sons, Hoboken, NJ, USA, 2004.

[38] S. Edward, "Forest genetic resources conservation: principles, strategies and actions," in Proceedings of the National Forest Genetic Resources Conservation Strategy Workshop, Addis Ababa, Ethiopia, June 1999.

[39] P. Chauhan and J. D. S. Negi, "Regeneration status of sal forests of doon valley," Annals of Forestry, vol. 16, no. 2, pp. 178-182, 2008.
[40] M. Dhaulkhandi, "Community structure and regeneration potential of natural forest site in Gangotri, India," Journal of Basic and Applied Sciences, vol. 4, no. 1, pp. 49-52, 2008.

[41] A. Dibaba, T. Soromessa, A. Kefalew, and A. Addi, "Woody species diversity, vegetation structure, and regeneration status of the moist afromontane forest of Agama in southwestern Ethiopia," International Journal of Ecology, vol. 2020, Article ID 1629624, 10 pages, 2020.

[42] F. Senbeta, "Plant diversity, vegetation structure and relationship between plant communities and environmental variables in the Afromontane Forests of Ethiopia," SINET: Ethiopian Journal of Science, vol. 37, no. 2, pp. 113-130, 2014.

[43] G. Boz and M. Maryo, "Woody species diversity and vegetation structure of Wurg forest, southwest Ethiopia," International Journal of Forestry Research, vol. 2020, Article ID 8823990, 17 pages, 2020.

[44] M. Kuma and S. Shibru, "Floristic composition, vegetation structure, and regeneration status of woody plant species of Oda forest of humbo carbon project, Wolaita, Ethiopia," Journal of Botany, vol. 2015, Article ID 963816, 9 pages, 2015.

[45] A. D. Hundie, T. S. Urgessa, and B. W. Dullo, Plant Community Analysis along Environmental Gradients in Moist Afromontane Forest of Gerba Dima, South-Western Ethiopia, Springer, Berlin, Germany, 2020.

[46] A. Shmida and M. V. Wilson, "Biological determinants of species diversity," Journal of Biogeography, vol. 12, no. 1, pp. 1-20, 1985.

[47] J. L. Vivero, E. Kelbessa, and S. Demissew, "Progress on the red list of plants of Ethiopia and Eritrea: conservation and biogeography of endemic flowering taxa," Taxonomy and Ecology of African Plants, Their Conservation and Sustainable Use, pp. 761-778, Royal Botanic Gardens, Kandy, Sri Lanka, 2006.

[48] A. Assefa, S. Demissew, and Z. Woldu, "Floristic composition, structure and regeneration status of Masha forest, south-west Ethiopia," African Journal of Ecology, vol. 52, no. 2, pp. 151-162, 2014.

[49] D. Edae and T. Soromessa, "Comparative analysis of structure and regeneration status of woody species in managed and community used forest sites in Gelesha kebele, Mejengir forest, Gambella national regional state Palgo," Journal of Agriculture, vol. 3, no. 1, pp. 118-131, 2016.

[50] M. K. Gautam, R. K. Manhas, and A. K. Tripathi, "Overstory structure and soil nutrients effect on plant diversity in unmanaged moist tropical forest," Acta Oecologica, vol. 75, pp. 43-53, 2016.

[51] F. O. Ademoh, J. I. Muoghalu, and B. Onwumere, “Temporal pattern of tree community dynamics in a secondary forest in southwestern Nigeria, 29 years after a ground fire," Global Ecology and Conservation, vol. 9, pp. 148-170, 2017.

[52] C. M. Sharma, A. K. Mishra, O. P. Tiwari, R. Krishan, and Y. S. Rana, "Regeneration patterns of tree species along an Elevational gradient in the Garhwal Himalaya," Mountain Research and Development, vol. 38, no. 3, pp. 211-219, 2018.

[53] B. Alemu, K. Hundera, and B. Abera, "Floristic composition and structural analysis of Gelesha forest, Gambella regional State, Southwest Ethiopia," Journal of Ecology and the Natural Environment, vol. 7, no. 7, pp. 218-227, 2015.

[54] K. Gebrehiwot and K. Hundera, "Species composition, plant community structure and natural regeneration status of Belete moist evergreen montane forest, Oromia Regional State, Southwestern Ethiopia," Momona Ethiopian Journal of Science, vol. 6, no. 1, pp. 97-101, 2014. 
[55] F. Gurmessa, T. Soromessa, and E. Kelbessa, "Structure and regeneration status of Komto afromontane moist forest, east wollega zone, west Ethiopia," Journal of Forestry Research, vol. 23, no. 2, pp. 205-216, 2012.

[56] E. Lulekal, E. Kelbessa, T. Bekele, and H. Yineger, "Plant species composition and structure of the Mana Angetu moist montane forest, south-eastern Ethiopia," Journal of East African Natural History, vol. 97, no. 2, pp. 165-185, 2008.

[57] H. Yineger, "Floristic composition and structure of the dry afromontane forest at Bale Mountains National Park, Ethiopia," SINET: Ethiopian Journal of Science, vol. 31, no. 2, pp. 103-120, 2008.

[58] K. Hundera and B. Deboch, "Woody species composition and structure of the gurra farda forest, snnpr, south wastern Ethiopia," Ethiopian Journal of Education and Sciences, vol. 3, no. 2, 2008.

[59] K. Yeshitela and T. Bekele, "The woody species composition and structure of Masha Anderacha forest, Southwestern Ethiopia," Ethiopian Journal of Biological Sciences, vol. 2, no. 1, pp. 31-48, 2003.

[60] H. Zegeye, D. Teketay, and E. Kelbessa, "Diversity, regeneration status and socio-economic importance of the vegetation in the islands of Lake Ziway, south-central Ethiopia," Flora-Morphology, Distribution, Functional Ecology of Plants, vol. 201, no. 6, pp. 483-498, 2006.

[61] D. Ellenberg and D. Mueller-Dombois, Aims and Methods of Vegetation Ecology, Wiley, New York, NY, USA, 1974.

[62] H. Lamprecht, Silviculture in the Tropics: Tropical Forest Ecosystems and Their Tree Species: Possibilities and Methods for Their Long-Term Utilization, Eschborn, DE: GTZ, Eschborn, Germany, 1989.

[63] A. Dibaba, T. Soromessa, E. Kelbessa, and A. Tilahun, "Diversity, structure and regeneration status of the woodland and riverine vegetation of Sire Beggo in Gololcha District, Eastern Ethiopia," Momona Ethiopian Journal of Science, vol. 6, no. 1, pp. 70-96, 2014.

[64] T. Mekonen, B. Ayele, and Y. Ashagrie, "Woody plant species diversity, structure and regeneration status of Woynwuha natural forest, North West Ethiopia," Journal of Agriculture and Environmental Sciences, vol. 1, no. 2, pp. 91-113, 2015.

[65] T. Bekele, "Phytosociology and ecology of a humid Afromontane forest on the central plateau of Ethiopia," Journal of Vegetation Science, vol. 5, no. 1, pp. 87-98, 1994.

[66] A. T. Ayalew, Vegetation Ecology and Carbon Stock of WofWasha Forest, North Shewa Zone, Amhara Region, Ethiopia, Addis Ababa University, Addis Ababa, Ethiopia, 2018.

[67] K. Hundera, T. Bekele, and E. Kelbessa, "Floristics and phytogeographic synopsis of a Dry Afromontane coniferous forest in the Bale Mountains (Ethiopia): implications to biodiversity conservation," SINET: Ethiopian Journal of Science, vol. 30, no. 1, pp. 1-12, 2007.

[68] A. Ayanaw Abunie and G. Dalle, "Woody species diversity, structure, and regeneration status of Yemrehane Kirstos church forest of lasta woreda, north wollo zone, amhara region, Ethiopia," International Journal of Forestry Research, vol. 2018, Article ID 5302523, 8 pages, 2018.

[69] D. Denu, "Floristic composition and ecological study of Bibita forest (gura ferda), southwest Ethiopia," Unpublished M. Sc. thesis, Addis Ababa University, Addis Ababa, Ethiopia, 2007.

[70] P. Murphey and A. Lugo, "Ecology of tropical dry forests," Annual Review of Ecology and Systematics, vol. 17, pp. 67-88, 1986.
[71] S. Alemu, M. Argaw, and E. Kelebisa, "Woody species composition, diversity and structural analysis of Angada forest in Merti Wereda, Arsi Zone of Oromia Region, Ethiopia," M. Sc. thesis, Addis Ababa University, Addis Ababa, Ethiopia, 2011.

[72] C. M. Peters, "Observations on the sustainable exploitation of non-timber tropical forest products," in proceedings of the Current Issues in Nontimber Forest Products Research, pp. 19-39, 1996.

[73] H. Hytteborn, J. R. Packham, and T. Verwijst, "Tree population dynamics, stand structure and species composition in the montane virgin forest of Vallibäcken, northern Sweden," Vegetatio, vol. 72, no. 1, pp. 3-19, 1987.

[74] F. A. Bazzaz and F. Bazzaz, Plants in Changing Environments: Linking Physiological, Population, and Community Ecology, Cambridge University Press, Cambridge, UK, 1996.

[75] K. J. Gaston, The Structure and Dynamics of Geographic Ranges, Oxford University Press on Demand, Oxford, UK, 2003.

[76] H. Yasin, Z. Kebebew, and K. Hundera, "Woody species diversity, regeneration and socioeconomic benefits under natural forest and adjacent coffee agroforests at Belete forest, southwest Ethiopia," Ekológia (Bratislava), vol. 37, no. 4, pp. 380-391, 2018.

[77] F. Temesgen and B. Warkineh, "Woody species structure and regeneration status in kafta sheraro national park dry forest, Tigray region, Ethiopia," International Journal of Forestry Research, vol. 2020, Article ID 4597456, 22 pages, 2020.

[78] H. A. Wale, T. Bekele, and G. Dalle, "Floristic diversity, regeneration status, and vegetation structure of woodlands in metema area, amhara national regional state, northwestern Ethiopia," Journal of Forestry Research, vol. 23, no. 3, pp. 391-398, 2012.

[79] P. S. Swamy, "Plant species diversity and tree population structure of a humid tropical forest in Tamil Nadu, India," Biodiversity and Conservation, vol. 9, no. 12, pp. 1643-1669, 2000.

[80] G. Yakob and A. Fekadu, "Diversity and regeneration status of woody species: the case of keja araba and tula forests, south west Ethiopia," OALib, vol. 3, no. 4, pp. 1-15, 2016.

[81] A. K. Saxena and J. S. Singh, "Tree population structure of certain Himalayan forest associations and implications concerning their future composition," Vegetatio, vol. 58, no. 2, pp. 61-69, 1984.

[82] A. W. Eshete, Ethiopian Church Forests: Opportunities and Challenges for Restoration, Wageningen Univeristy, Wageningen, Netherlands, 2007.

[83] T. Bogale, D. Datiko, and S. Belachew, "Structure and natural regeneration status of woody plants of berbere afromontane moist forest, bale zone, South East Ethiopia; implication to biodiversity conservation," Open Journal of Forestry, vol. 7, no. 3, p. 352, 2017.

[84] G. Fisaha, K. Hundera, and G. Dalle, "Woody plants' diversity, structural analysis and regeneration status of Wof Washa natural forest, North-east Ethiopia," African Journal of Ecology, vol. 51, no. 4, pp. 599-608, 2013.

[85] M. Siraj and K. Zhang, "Structure and natural regeneration of woody species at central highlands of Ethiopia," Journal of Ecology and The Natural Environment, vol. 10, no. 7, pp. 147-158, 2018.

[86] T. Gemechu, T. Soromessa, and E. Kelbessa, "Structure and regeneration of gendo moist montane forest, east wellega zone, western Ethiopia," Journal of Environmental \& Earth Sciences, vol. 5, no. 15, pp. 148-168, 2015. 
[87] E. Birhane, D. Teketay, and P. Barklund, "Enclosures to enhance woody species diversity in the dry lands of eastern Tigray, Ethiopia," East African Journal of Sciences, vol. 1, no. 2, pp. 136-147, 2007.

[88] D. P. J. Kuijper, J. P. G. M. Cromsigt, B. Jędrzejewska et al., "Bottom-up versus top-down control of tree regeneration in the Białowieża Primeval Forest, Poland," Journal of Ecology, vol. 98, no. 4, pp. 888-899, 2010.

[89] N. Norden, R. C. G. Mesquita, T. V. Bentos, R. L. Chazdon, and G. B. Williamson, "Contrasting community compensatory trends in alternative successional pathways in central Amazonia," Oikos, vol. 120, no. 1, pp. 143-151, 2011.

[90] H. Zegeye, D. Teketay, and E. Kelbessa, "Diversity and regeneration status of woody species in Tara Gedam and Abebaye forests, northwestern Ethiopia," Journal of Forestry Research, vol. 22, no. 3, pp. 315-328, 2011.

[91] M. T. Asmare and A. Gure, "Effect of exclosure on woody species diversity and population structure in comparison with adjacent open grazing land: the case of Jabi Tehnan district north western Ethiopia," Ecosystem Health and Sustainability, vol. 5, no. 1, pp. 98-109, 2019.

[92] E. N. Mwavu and E. T. F. Witkowski, "Population structure and regeneration of multiple-use tree species in a semideciduous African tropical rainforest: implications for primate conservation," Forest Ecology and Management, vol. 258, no. 5, pp. 840-849, 2009.

[93] M. Sarkar and A. Devi, "Assessment of diversity, population structure and regeneration status of tree species in Hollongapar Gibbon Wildlife Sanctuary, Assam, Northeast India," Tropical Plant Research, vol. 1, no. 2, pp. 26-36, 2014.

[94] B. Abiyot and A. Zemede, "The role of home gardens for conservation and sustainable utilization of plant biodiversity of Ethiopia," in proceedings of the Coffee Production, Variety and Trading Ways to Maximize Ethiopia's Benefits, pp. 81-35, Addis Ababa, Ethiopia, 2014.

[95] J. A. Bhat, A. K. Negi, and N. P. Todaria, "Regeneration status of woody species in a protected area of Western Himalaya," Acta Ecologica Sinica, vol. 35, no. 3, pp. 51-58, 2015.

[96] M. Lemenih, T. Gidyelew, and D. Teketay, "Effects of canopy cover and understory environment of tree plantations on richness, density and size of colonizing woody species in southern Ethiopia," Forest Ecology and Management, vol. 194, no. 1-3, pp. 1-10, 2004.

[97] Y. L. Vargas-Rodriguez, J. A. Vázquez-García, and G. B. Williamson, "Environmental correlates of tree and seedling-sapling distributions in a Mexican tropical dry forest," Plant Ecology, vol. 180, no. 1, pp. 117-134, 2005.

[98] E. Romell, Aspects of regeneration in Tropical Secondary Forests of Northeast Borneo Affected by Selective Logging, El Niño-Induced Drought and Fire, Swedish University of Agricultural Sciences, Uppsala, Sweden, 2011.

[99] M. Fazlollahi Mohammadi, S. G. Jalali, Y. Kooch, and T. A. Theodose, "Tree species composition, biodiversity and regeneration in response to catena shape and position in a mountain forest," Scandinavian Journal of Forest Research, vol. 32, no. 1, pp. 80-90, 2017.

[100] M. R. Darrigo, E. M. Venticinque, and F. A. M. d. Santos, "Effects of reduced impact logging on the forest regeneration in the central Amazonia," Forest Ecology and Management, vol. 360, pp. 52-59, 2016.

[101] R. A. Montgomery, P. B. Reich, and B. J. Palik, "Untangling positive and negative biotic interactions: views from above and below ground in a forest ecosystem," Ecology, vol. 91, no. 12, pp. 3641-3655, 2010.
[102] R. K. Kobe and C. F. Vriesendorp, "Conspecific density dependence in seedlings varies with species shade tolerance in a wet tropical forest," Ecology Letters, vol. 14, no. 5, pp. 503-510, 2011. 